\title{
The Nuclear Hormone Receptor PPAR $\gamma$ as a Therapeutic Target in Major Diseases
}

\author{
Martina Victoria Schmidt, Bernhard Brüne, and Andreas von Knethen* \\ Institute of Biochemistry I-Pathobiochemistry, Faculty of Medicine, Goethe- \\ University Frankfurt, Germany \\ E-mail: $\underline{\text { m.schmidt@zbc.kgu.de; bruene@zbc.kgu.de; v knethen@zbc.kgu.de }}$
}

Received July 29, 2010; Revised October 12, 2010, Accepted October 25, 2010; Published November 4, 2010

The peroxisome proliferator-activated receptor $\gamma$ (PPAR $\gamma$ ) belongs to the nuclear hormone receptor superfamily and regulates gene expression upon heterodimerization with the retinoid $X$ receptor by ligating to peroxisome proliferator response elements (PPREs) in the promoter region of target genes. Originally, PPAR $\gamma$ was identified as being essential for glucose metabolism. Thus, synthetic PPAR $\gamma$ agonists, the thiazolidinediones (TZDs), are used in type 2 diabetes therapy as insulin sensitizers. More recent evidence implied an important role for the nuclear hormone receptor PPAR $\gamma$ in controlling various diseases based on its anti-inflammatory, cell cycle arresting, and proapoptotic properties. In this regard, expression of PPAR $\gamma$ is not restricted to adipocytes, but is also found in immune cells, such as B and T lymphocytes, monocytes, macrophages, dendritic cells, and granulocytes. The expression of PPAR $\gamma$ in lymphoid organs and its modulation of macrophage inflammatory responses, lymphocyte proliferation, cytokine production, and apoptosis underscore its immune regulating functions. Moreover, PPAR $\gamma$ expression is found in tumor cells, where its activation facilitates antitumorigenic actions. This review provides an overview about the role of PPAR $\gamma$ as a possible therapeutic target approaching major, severe diseases, such as sepsis, cancer, and atherosclerosis.

KEYWORDS: PPAR $\gamma$, immune regulation, sepsis, atherosclerosis, cancer

\section{PPAR $\gamma$-DEPENDENT ANTI-INFLAMMATORY MECHANISMS}

Inflammatory conditions typify the host's response to external challenges, or cellular injury causes activation of diverse inflammatory mediators to modify tissue structure and function. A prolonged inflammatory state with the release of proinflammatory cytokines and reactive oxygen species (ROS) from activated leukocytes can, in turn, destruct tissue, thereby contributing to the pathogenesis of many disease states[1,2]. Therefore, attention is being paid to factors that operate as negative regulators of inflammatory responses. Recently, peroxisome proliferator-activated receptor $\gamma$ (PPAR $\gamma$; NR1C3), a member of the nuclear receptor superfamily, has been demonstrated to provoke and mediate antiinflammatory signaling[3]. Originally, it was identified as a key regulator of adipocyte differentiation[4] and glucose metabolism[5]. PPAR $\gamma$ acts as a transcriptional activator of many adipocyte-specific genes 
involved in lipid synthesis, handling and storage of lipids, growth regulation, insulin signaling, and adipokine production[6]. PPAR $\gamma$ binds to peroxisome proliferator response elements (PPREs) as a heterodimer with members of the retinoid X receptor (RXR; NR2B) subfamily, provoking target gene expression. Moreover, PPAR $\gamma$ has been shown to inhibit the expression of proinflammatory cytokines, such as tumor necrosis factor $\alpha(\mathrm{TNF} \alpha)$, interleukin (IL)-1 $\beta$, and IL-6[2,7]. In monocytes/macrophages, PPAR $\gamma$ activation suppresses inducible nitric oxide synthase (iNOS) up-regulation[8] and ROS production[8,9]. Identification of molecular mechanisms responsible for the anti-inflammatory action of PPAR $\gamma$ is thus likely to be of practical importance in the efforts to develop safer and more effective drugs for the treatment of diseases associated with or caused by chronic or overwhelming inflammation.

So far, five different mechanisms are proposed for PPAR $\gamma$ to alter gene expression (Fig. 1)[2,10]. A major mechanism, mediated by the ability of PPAR $\gamma$ to cross-talk with proinflammatory signaling pathways, interfering with transcription factor activation has been termed transrepression. Transrepression involves protein-protein interactions between PPAR $\gamma$ and transcription factors, such as NF- $\kappa B[11,12,13]$, NFAT[14], AP-1[13,15], or STAT[16] (Fig. 1A). This mechanism scavenges transcription factors from binding to their responsive elements rather than a direct sequence-specific interaction of PPAR $\gamma$ with DNA itself. This assigns PPAR $\gamma$ the ability to inhibit proinflammatory signaling and to induce an anti-inflammatory response. In immune cells, PPAR $\gamma$ activation thus attenuates expression of proinflammatory mediators, such as IL-2, TNF $\alpha$, IL-1 $\beta$, and IL-12. PPAR $\gamma$-dependent transrepression can also be mediated by PPAR $\gamma$ binding to coactivator complexes, such as steroid receptor co-activator 1 (SRC1) and cAMP response element binding (CREB)-binding protein (CBP)/p300, which are essential for transcription factordependent transactivation (Fig. 1B). These coactivator complexes usually reorganize the chromatin packaging through their histone acetyltransferase activity, to allow the transcriptional machinery gaining access to the promoter region[17]. Because these transcriptional coactivators are indispensable for AP1mediated gene induction[18] and enhance NF- $\kappa \mathrm{B}$-dependent transcription[19], proinflammatory gene expression is inhibited. SUMOylated PPAR $\gamma$ can transrepress gene expression by preventing removal of the corepressor complex nuclear receptor corepressor/silencing mediator for retinoid and thyroid hormone receptors (NCoR/SMRT) from the promoter region of proinflammatory transcription factors, e.g., NF- $\mathrm{B}$, which, through association with histone deacetylases (HDACs), attenuates gene transcription (Fig. 1C) [20,21]. Besides transrepression, PPAR $\gamma$ can inhibit mitogen-activated protein kinase (MAPK) by a sofar-unknown mechanism[22,23,24]. This inhibition prevents MAPK from phosphorylating and thereby activating downstream transcription factors, which are necessary for MAPK-dependent proinflammatory gene expression (Fig. 1D). Additionally, cytosolic PPAR $\gamma$ is able to bind protein kinase $\mathrm{C} \alpha$ (PKC $\alpha$ ) directly, subsequently inhibiting $\mathrm{PKC} \alpha$ translocation to the cell membrane, its activation, and further depletion. This provokes monocyte/macrophage desensitization in response to apoptotic cell phagocytosis, where attenuated PKC $\alpha$ signaling blocks NADPH-oxidase-dependent ROS formation (Fig. 1E)[25]. Casein kinase II (CK-II)-dependent PPAR $\gamma$ phosphorylation makes PPAR $\gamma$ accessible for the CRM1-dependent nuclear export machinery, consequently triggering cytosolic PPAR $\gamma$ localization. This process involves RanGTP and phosphorylation of RanBP3 to shuttle PPAR $\gamma$ to the cytosol efficiently[9,26].

\section{CONSEQUENCES OF PPAR $\gamma$ ACTIVATION IN IMMUNE CELLS}

PPAR $\gamma$ activation in immune cells predominantly results in transrepression of proinflammatory gene expression. PPAR $\gamma$ agonists have been shown to decrease IL-2 production in activated T cells and thereby to enhance apoptosis[14,27,28,29]. Additionally, PPAR $\gamma$ ligands can inhibit activation-induced production of several T-cell cytokines, including the classical $\mathrm{T}_{\mathrm{H}} 1$-cell cytokine interferon $\gamma$ (IFN $\gamma$ )[30]. The ability of ligand-activated PPAR $\gamma$ to inhibit IL-12 production by dendritic cells, as well as its ability to inhibit IFN $\gamma$ production by $\mathrm{T}$ cells, indicates that this nuclear hormone receptor might play a role during differentiation of naïve $\mathrm{T}$ cells into their effector subsets. Conversely, it was shown that the presence 


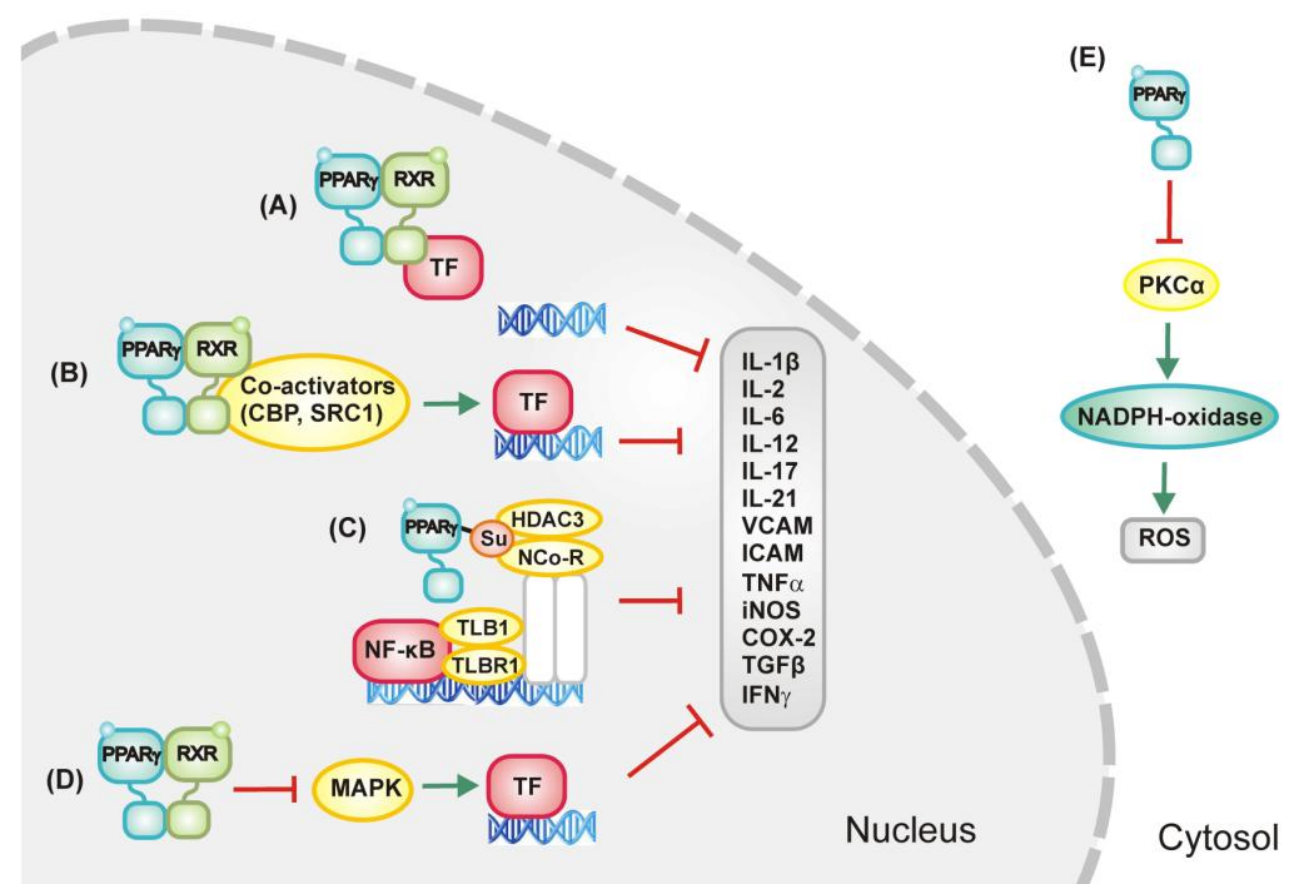

FIGURE 1. Mechanisms of PPAR $\gamma$-dependent inhibition of proinflammatory gene expression. In response to agonist, PPAR $\gamma$ can form a heterodimer with the RXR $\alpha$. In this heterodimeric state, PPAR $\gamma$ (A) directly associates with proinflammatory transcription factors (TF), such as NF- $\mathrm{KB}$, STAT, and AP-1, and prevents proinflammatory gene expression; (B) scavenges transcriptional coactivators, such as CBP and SRC-1 from binding to proinflammatory transcription factors (TF), enhancing the expression of proinflammatory genes. (C) In response to its SUMOylation (Su), PPAR $\gamma$ inhibits proteasomal degradation of the NCoR/HDAC3/TLB1/TLBR1 complex, which in turn would allow NF- $\mathrm{kB}$-dependent proinflammatory gene expression. (D) Besides these three mechanisms of transrepression, PPAR $\gamma$ inhibits MAPK to attenuate downstream signaling, which is necessary to induce proinflammatory gene expression. (E) Finally, activated PPAR $\gamma$ is assumed to inhibit PKC $\alpha$ translocation, thereby attenuating NADPH oxidase activation. In C and E, heterodimer formation with $\mathrm{RXR} \alpha$ is not required.

of IL-4, a cytokine important for the development of $\mathrm{T}_{\mathrm{H}} 2$ cells[31], can provide a potential PPAR $\gamma$ specific ligand through up-regulation of the 12/15 lipoxygenase in monocytes[32]. This enzyme produces 13-hydroxyoctadecadienoic acid (13-HODE), which in turn suppresses the production of IL-4 in monocytes. Furthermore, 13-HODE can be taken up by $\mathrm{T}$ cells to activate PPAR $\gamma$, thus promoting a $\mathrm{T}_{\mathrm{H}} 2$ effector phenotype, where PPAR $\gamma$ is highly expressed[32,33]. These observations suggest that PPAR $\gamma$ may contribute to the anti-inflammatory activities of IL-4 and that full proinflammatory activities require down-regulation of PPAR $\gamma$. Previous results demonstrated that the inhibitory effects of the PPAR $\gamma$ agonist rosiglitazone upon LPS and IFN $\gamma$ stimulation are PPAR $\gamma$ dependent when the drug is used at concentrations close to its binding affinity. At high concentrations, the inhibitory effects are PPAR $\gamma$ independent and probably mediated, at least in part, by the unspecific activation of PPAR $\delta[34]$.

Further, PPAR $\gamma$ plays a crucial role in autoimmune diseases, such as multiple sclerosis. Th17 cells provide protection towards (certain) infections, but more importantly, these cells have been linked to the development of autoimmunity. Th17 differentiation critically depends on transforming growth factor $\beta$ (TGF $\beta$ ), together with proinflammatory cytokines like IL-6 or IL-21. Thus, PPAR $\gamma$ blocks TGF $\beta /$ IL-6dependent expression of the retinoid receptor-related orphan receptor $\gamma \mathrm{t}(\mathrm{ROR} \gamma \mathrm{t})$, the key transcription factor for Th17 differentiation, making them more amenable to pharmacological modulations[35]. 


\section{PPAR $\gamma$ AND SEPSIS}

In the course of sepsis, one of the most severe inflammatory processes, PPAR $\gamma$ acts as a double-edged sword. On the one hand, by attenuating NF- $\kappa B$ transactivation, PPAR $\gamma$ inhibits cytokine expression of, for example, TNF $\alpha$ or IL-12[36], the expression of vascular cell adhesion molecule-1 (VCAM-1), and intercellular adhesion molecule-1 (ICAM-1)[37]. Moreover, the expression of the inducible proinflammatory proteins, cyclo-oxygenase-2[15], cytosolic phopholipase A2, and inducible nitric oxide synthase (iNOS)[8], are blocked[38,39]. In vivo studies showed that administration of the PPAR $\gamma$ agonist 15 -deoxy- $\Delta^{12,14}$-prostaglandin $\mathrm{J} 2\left(15 \mathrm{~d}-\mathrm{PGJ}_{2}\right)$ prior to polymicrobial sepsis reduces lung injury and neutrophil trafficking to the lung and small intestine[40]. 15d-PGJ $\mathrm{J}_{2}$ enhances PPAR $\gamma$ functions in the lung, decreases NF- $\kappa \mathrm{B}$ activity, and promotes expression of the cytoprotective heat shock protein 70 (HSP70)[41]. In turn, the heat shock response is amplified and correlates well with improved lung injury. In the study of Matsui et al., it is proposed that the ability of $15 \mathrm{~d}-\mathrm{PGJ}_{2}$ to block cytokine-induced iNOS in macrophages is associated with the expression of HSP70[42]. Correspondingly, the duration and extent of $\mathrm{NF}-\mathrm{KB}$ activation corresponds with the severity of the inflammatory response, i.e., it persists longer in nonsurviving than in surviving patients with acute sepsis. In these studies, it has been suggested that PPAR $\gamma$ modulates expression of inflammatory genes by transrepression. However, $15 \mathrm{~d}-\mathrm{PGJ}_{2}$ has also been reported to alter NF- $\kappa B$ activation directly, independent of PPAR $\gamma$ in sepsis[43]. Straus et al. provided mechanistic evidence that $15 \mathrm{~d}-\mathrm{PGJ}_{2}$ directly inhibits $\mathrm{NF}-\kappa \mathrm{B}-$ dependent gene expression through covalent modifications of critical cysteine residues in I $\kappa \mathrm{B}$ kinase and the DNA-binding domains of NF$\kappa \mathrm{B}$ subunits[44].

Conversely, PPAR $\gamma$ seems to play a pivotal role in the compensatory anti-inflammatory response syndrome. This describes the later phase in the course of sepsis, where the body responds with antiinflammatory cytokine production as well as a massive apoptosis of immune cells to diminish selfharmful effects[45,46]. Hotchkiss and colleagues even showed that depletion of lymphocytes is the central pathogenic event during sepsis and contributes severely to a bad outcome of sepsis[45,47,48,49,50]. In mice, blocking T-cell apoptosis by overexpression of the antiapoptotic Bcl-2 protein[51,52,53] or by depletion of proapoptotic Bim[54,55,56,57,58] resulted in a higher survival rate compared to wild-type controls in response to the cecal ligation and puncture (CLP)-dependent polymicrobial sepsis. Previous results of our group showed that PPAR $\gamma$ also induces apoptosis in T cells by a yet-unknown mechanism. When primary human $\mathrm{T}$ cells of septic patients are stimulated with PPAR $\gamma$ agonists, they undergo apoptosis. In line, in these activated T cells, PPAR $\gamma$ expression is increased. Moreover, the serum of sepsis patients provoked PPAR $\gamma$ transactivation, suggesting that it contains a specific PPAR $\gamma$ agonist whose nature has so far not been clarified[59,60]. PPAR $\gamma$ activation during the onset of sepsis, as an endogenous anti-inflammatory factor, is suggested to prevent sepsis progression by attenuating the hyperinflammatory response. During the later phase of sepsis, PPAR $\gamma$ activation might enhance immune paralysis by contributing to T-cell apoptosis, thus worsening the septic outcome. Therefore, under these conditions, antagonizing PPAR $\gamma$ might be more appropriate.

\section{PPAR $\gamma$ AND CANCER}

In tumorigenesis, it has been controversially discussed whether the role of PPAR $\gamma$ is pro-oncogenic or antineoplastic. Previous observations suggest a multifaceted and tissue-specific effect of PPAR $\gamma$. For colon cancer, it has been shown that PPAR $\gamma$ retards the growth of cultured cell carcinomas or implanted tumors, whereas in colon epithelium, proliferation is favored. Tumor-restricted PPAR $\gamma$ expression, as shown for colon, breast, and bladder cancer, modifies tumor development, prolonging survival, lowering mortality, and consequently accounting for a good prognosis. Indeed, more and more studies demonstrate a number of antineoplastic processes initiated by PPAR $\gamma$. In this line especially, its antiproliferative 
effects, such as arresting the cell cycle and causing cell differentiation, as well as inhibition of angiogenesis and induction of apoptosis, are discussed as possible antineoplastic mechanisms of PPAR $\gamma$.

In 2001, Patel et al. observed that PPAR $\gamma$ induces expression of the phosphatase and tensin homolog on chromosome ten (PTEN) in MCF-7 breast carcinoma and $\mathrm{CaCo}_{2}$ colon cancer cell lines, possibly by binding to two putative PPREs identified within the PTEN promoter[61]. As a result of up-regulated PTEN, Akt phosphorylation and concomitant cell proliferation was significantly reduced. Two other studies further confirmed this initial report[62,63]. Moreover, in the latter, it was shown that PPAR $\gamma$ dependent PTEN expression can be blocked by estrogen receptor binding to the PPRE site of the PTEN promoter[63]. This cross-talk has to be carefully considered when new therapy approaches are developed.

Through the identification of genetically damaged cells, the tumor-suppressor protein p53 minimizes the risk of harmful mutations by either pausing the cell cycle for repair or eliminating the cell by apoptosis. p53 achieves many of its roles through induction of target genes, to arrest the cell cycle via $\mathrm{p} 21$ (Cip1/WAF1) or to induce apoptosis via the proapoptotic Bax. Of particular significance in this line is the ability of PPAR $\gamma$ to enhance p53 expression, by binding to the NF- $\kappa \mathrm{B}$-responsive element, located in the promoter region of p53[64]. However, in 2008, Zaytseva et al. demonstrated that down-regulation of PPAR $\gamma$ suppresses cell growth and induces apoptosis in MCF-7 breast cancer cells[65]. Previous work showed that a distinct promoter regulates PPAR $\gamma$ expression in MCF-7 cells, and that promoter switching causes differential PPAR $\gamma$ expression between normal and cancer cells[66,67]. Recently, the authors provided evidence that a knockdown of PPAR $\gamma$ in MCF-7 cells blocks proliferation, decreasing cell transition from the G1 to the $S$ phase. Since these studies were performed only in breast cancer cell lines, one may speculate that these observations are cell-type specific. PPAR $\gamma$ has been shown to alter carcinogenesis in other tumors as well. A recent work by Yu et al. implicated an inhibitory role of PPAR $\gamma$ in hepatocarcinogenesis[68]. In this case, an animal model was used to genetically ablate PPAR $\gamma$ expression on one allele $\left(\operatorname{PPAR} \gamma^{+-}\right)$, which decreases PPAR $\gamma$ expression, but is not lethal during embryogenesis like total PPAR $\gamma$ knockout $\left(\operatorname{PPAR} \gamma^{-1}\right)$. Using a diethylnitrosamine (DEN)-induced hepatocarcinoma cell (HCC) model, the authors showed that activation of PPAR $\gamma$ by rosiglitazone blocked tumor development in PPAR $\gamma$ wild-type $\left(\operatorname{PPAR} \gamma^{+/+}\right)$littermates, whereas it did not alter tumor formation in PPAR $\gamma^{+/-}$mice. To elucidate the underlying mechanism, the authors transduced the human hepatoma cell line Hep3B with a PPAR $\gamma$-expressing adenovirus. In these transduced cells, PPAR $\gamma$ overexpression induced a G2/M arrest and apoptosis, mediated by extrinsic (Fas+TNF $\alpha$ ) and intrinsic (caspases 3, 7, 9, and PARP) pathways. Both, cell cycle arrest and cell death were additively enhanced in response to rosiglitazone-mediated PPAR $\gamma$ activation. Moreover, PPAR $\gamma$ overexpression induced expression of the growth differentiation factor-15 (GDF-15), which has been established to attenuate proliferation in other tumor systems as well[69,70,71]. These in vitro data were finally corroborated in the liver tissue of PPAR $\gamma^{+/+}$mice by immunohistochemistry. There, GDF-15 expression in response to rosiglitazone significantly increased compared to untreated control animals or rosiglitazone-stimulated heterozygous littermates. The authors conclude that PPAR $\gamma$ functions as a tumor suppressor in hepatocarcinogenesis[68].

In other studies, impairment of the intact PPAR $\gamma$ permits tumorigenesis. In a subset of thyroid follicular carcinomas, a chromosomal translocation $(\mathrm{t}(2 ; 3)(\mathrm{q} 13 ; \mathrm{p} 25))$ results in the expression of a paired box gene-8 (PAX8)-PPAR $\gamma$ fusion protein[72]. This fusion protein cannot be activated by agonists such as rosiglitazone and, thus, constitutes a dominant-negative protein. Overexpression of the PAX8/PPAR $\gamma$ fusion protein stimulated the proliferation of primary human thyroid cells, suggesting that the PPAR $\gamma$ moiety-dependent transactivation of this fusion protein is an essential component in its tumorigenic action[73,74]. For other cancers, such as bladder cancer, it was shown that mutations block the formation and functionality of PPAR $\gamma$. Hence, heterodimerization with RXR and binding to the responsive element on the DNA is inhibited, impairing the induction of antitumorigenic activity.

Colon cancer cells that were exposed to PPAR $\gamma$ exhibited a G1 cell cycle arrest and increased expression of the carcinoembryonic antigen. Moreover, activation of PPAR $\gamma$ up-regulates cavedin-1, a 
tumor-suppressor protein. This was abrogated by treatment with the PPAR $\gamma$ antagonist GW9662, showing that PPAR $\gamma$ agonist-induced tumor suppression is specifically initiated by activation of the PPAR $\gamma$ pathway. This was confirmed in a mouse model of human bladder cancer, where treatment with PPAR $\gamma$ agonists significantly inhibited tumor growth[75].

In human glioma cells, stimulation with ciglitazone or troglitazone resulted in a concentration- and time-dependent apoptotic cell death. Herein, ciglitazone-induced ROS generation and cell death were prevented by the antioxidant $\mathrm{N}$-acetylcysteine, suggesting an important role of ROS generation for ciglitazone-induced apoptosis. Apoptosis could be inhibited by the PPAR $\gamma$ antagonist GW9662[76]. Thus, induction of PPAR $\gamma$-dependent apoptosis may be a promising therapeutic approach in cancer therapy.

Tumor development is associated with accumulation of genetic changes, which ultimately produce a pronounced inflammatory phenotype that is also aggressive in growth and relatively resistant to chemotherapy. Although acute inflammation is a necessary process aimed at protecting the organism after an injury, unresolved chronic inflammation may promote cancer formation by providing an appropriate environment for tumor growth[77,78,79]. Although mechanisms that link inflammation and cancer have only been studied rudimentarily, epidemiological studies show a convincing association between them[80,81]. Thus, cytokines that are released in response to infection, inflammation, and immunity can function to inhibit tumor development and progression. Alternatively, cancer cells can respond to hostderived cytokines that promote growth, attenuate apoptosis, and facilitate invasion and metastasis. Proinflammatory cytokines implicated in carcinogenesis include IL-1, IL-6, IL-15, colony stimulating factor, $\mathrm{TNF} \alpha$, and the macrophage migration inhibitory factor. In this context, tumor-associated macrophages (TAM) seem to be especially important. They display a phenotype similar to M2-polarized macrophages, which are characterized by the expression of anti-inflammatory cytokines such as IL-10 and proangiogenic factors, e.g., vascular endothelial growth factor (VEGF)[82]. By contributing to vascular supply and to vascular endothelial cell proliferation, they play a critical role in the maintenance and development of cancer. Fauconnet et al. showed that PPAR $\gamma$ expression correlates with VEGF expression. This was verified by reporter gene experiments showing ligand-mediated PPAR $\gamma$-dependent VEGF transcription[83]. Macrophage polarization to the M2 phenotype has been linked in part to PPAR $\gamma$ activation $[84,85,86]$, mainly attributed to its role in transrepressing proinflammatory gene expression. Recently, in a mouse model of progressing T lymphoma, M2 macrophages blocked cytotoxicity of CD8 ${ }^{+}$ T lymphocytes (CTL)[87]. Stimulation of these M2 macrophages with PPAR $\gamma$ agonists restored CTLdependent cytotoxicity towards tumor cells. Therefore, PPAR $\gamma$ might be a new potential therapeutic target to abrogate macrophage-mediated CTL suppression in cancer. Additional support for a role of PPAR $\gamma$ in macrophage-dependent attenuation of tumor development came from a study by Shah et al. The authors provide evidence that mice with a targeted disruption of PPAR $\gamma$ in macrophages displayed an increased susceptibility to dextran sulfate sodium (DSS)-induced colitis compared to PPAR $\gamma$ wild-type littermates[88]. The data suggest that PPAR $\gamma$ regulates macrophage recruitment to inflammatory foci in the colon.

The role of PPAR $\gamma$ in physiology and pathophysiology should be clarified, since this may increase our understanding of how cancer occurs and how it can be treated. While the identities of target genes that contribute to the antiproliferative activities of PPAR $\gamma$ agonists remain largely elusive, accumulating evidence indicates that TZDs mediate PPAR $\gamma$-independent antitumor effects by targeting diverse signaling cascades governing proliferation and survival of cancer cells [89]. Several studies using PPAR $\gamma$ deficient mouse models support this assumption. PPAR $\gamma$ deletion in hepatocytes in a hepatitis B virus transgenic mouse model did not alter hepatic carcinogenesis, but increased the TZD-mediated antitumorigenic effect when compared to PPAR $\gamma$ wild-type mice[90]. Moreover, TZDs inhibited invasiveness of pancreatic cancer cells derived from human pancreatic adenocarcinomas via PPAR $\gamma$ independent mechanisms[91]. Although TZDs can attenuate tumor development or progression PPAR $\gamma$ independently, many human cancer cells have been shown to exhibit high levels of PPAR $\gamma$. Exposure of these tumor cells to high doses of PPAR $\gamma$ agonists provoked cell cycle arrest, apoptosis, and 
redifferentiation, suggesting a link between PPAR $\gamma$ signaling and the antitumor activities of PPAR $\gamma$ ligands. Energy balance, obesity, and lack of exercise are leading nongenetic predispositions that cause an increased tumor risk. PPAR $\gamma$ could herein act as the potential link between energy balance, cellular metabolism, and cancer pathogenesis. However, the exact role of PPAR $\gamma$ during carcinogenesis and tumor cell growth is still unclear.

\section{PPAR $\gamma$ AND ATHEROSCLEROSIS}

Activation of PPAR $\gamma$ is an important anti-inflammatory strategy during inflammation[17]. Originally, PPAR $\gamma$ was described as a transcription factor belonging to the hormone receptor superfamiliy, localized in the nuclear membrane, regulating glucose and lipid metabolism[5]. Thus, a major role of PPAR $\gamma$ in the pathogenesis of obesity, diabetes, and arteriosclerosis can be deviated[92]. The antidiabetic synthetic TZDs operate by specifically activating PPAR $\gamma[93,94]$. These drugs enhance the effect of insulin and lower the level of serum glucose[95]. A recent review by Kaul et al. summarizes evidence from recent trials analyzing the long-term effect of TZD use. These data suggest that rosiglitazone is associated with an increased risk of cardiovascular events, and pioglitazone and rosiglitazone are associated with higher rates of heart failure[96]. PPAR $\gamma$ activation by the TZDs results in an array of effects on traditional and nontraditional cardiovascular risk factors that are independent of their effects on glycemic control. These include, for example, reduction of intermedia thickness progression[97] and circulating platelet activity[98], attenuation of PAI-1 expression[99], inhibition of glycation[100], increase in plasma adiponectin[101], and reduction of CRP[102], IL-6[103], and MMP-9 levels[104]. However, further trials are necessary to determine to which extent the different factors contribute to TZD-dependent cardiovascular alterations.

During atherogenesis, PPAR $\gamma$ is expressed by activated monocytes and macrophages. As a first step, monocytes are attracted to the vessel wall of large arteries by activated endothelial cells. Having attached by binding to selectins and integrins, monocytes infiltrate into the subendothelial space, mostly following a chemokine gradient, e.g., IL-8, originating from the source of infection, where they differentiate to macrophages[105]. Already this step is altered in response to PPAR $\gamma$ activation. Thus, troglitazone inhibited formation of early atherosclerotic lesions in low-density lipid receptor knockout (LDL- $\mathrm{R}^{-1}$ ) mice by decreasing macrophage accumulation in the intima, consistent with the in vitro observation that rosiglitazone as well as troglitazone inhibited MCP-1-directed transendothelial migration of monocytes[106]. A study transplanting bone marrow derived from macrophage-specific PPAR $\gamma$ knockout $\left(\mathrm{M} \Phi-\mathrm{PPAR} \gamma^{--}\right.$) mice into LDL- $\mathrm{R}^{--}$and control mice supported this observation. Macrophages derived from MФ-PPAR $\gamma^{-1-}$ showed increased migration and CC chemokine receptor 2 (CCR2) expression[107], which is the receptor for MCP-1. In the intima, macrophages scavenge trapped lipoproteins, such as oxLDL, leading to the formation of so-called foam cells and subsequent activation of these lipid-laden macrophages[108]. This contributes to the established designation of arteriosclerosis as a chronic inflammatory disease[109]. However, the role of PPAR $\gamma$ expression in these cells of monocytic origin is controversially discussed. Activation of PPAR $\gamma$ enhances oxLDL uptake by up-regulating CD36 expression, a class B scavenger receptor, consequently fostering foam cell formation[110]. On the other hand, PPAR $\gamma-$ dependent expression of the liver X receptor $\alpha(\mathrm{LXR} \alpha)$ provokes a decrease of intracellular cholesterol accumulation. As a heterodimer in combination with the RXR, LXR $\alpha$ induces expression of the ATPbinding cassette transporter A1 (ABCA1), causing lipid export from macrophages and thus counteracting foam cell generation[111]. Experiments using either PPAR $\gamma$-negative embryonic stem cells or macrophages from MФ-PPAR $\gamma^{-1-}$ mice support both of the described PPAR $\gamma$-dependent effects[112,113].

As recently reviewed by Mosser and Edwards[114], these differences might be attributed to macrophage plasticity. Macrophages are versatile immune cells that, depending on environmental stimuli, acquire diverse functional states. The extremes of this continuum are defined as the classically activated M1 and the alternatively activated M2 phenotype[115]. However, the alternative M2 definition does not 
satisfy and mirror the compelling evidence gathered over the last few years any more, since the M2 designation comprises macrophages with dramatic differences in their biochemistry and physiology[116].

The M1 macrophage phenotype is established in response to stimuli, like the bacterial cell wall component LPS and IFN $\gamma$, released mainly by $\mathrm{T}_{\mathrm{H}} 1$ cells. These activators are rapidly generated following infection or injury. M1 macrophages are characterized by an enhanced microbicidal capacity, elicited by proinflammatory mediator production such as TNF $\alpha$, IL-1 $\beta$, IL-6, IL-12, NO, or ROS[117,118]. Concerning the stimulation regime provoking M1 macrophage activation, one has to keep in mind that LPS treatment rapidly down-regulates PPAR $\gamma$ after $6-15$ h by miR27b-dependent mRNA destabilization[119], followed by its up-regulation again at later time points[120,121]. Support for this assumption came from Dos Santos Mendes et al., recently demonstrating that LPS stimulation of RAW 264.7 macrophages for $24 \mathrm{~h}$ transactivated PPAR $\gamma$, as observed by PPRE reporter analysis[122]. In analogy, we have shown PPAR $\gamma$ DNA binding (EMSA) and transactivation (reporter assay) in response to LPS/IFN $\gamma$-treatment for $15 \mathrm{~h}$, further underlining the notion of PPAR $\gamma$ activation after prolonged LPS stimulation[123].

Alternative activation of macrophages with, for example, glucocorticoids, IL-4, IL-13, or IL-10, induces an anti-inflammatory $\mathrm{M} 2$ phenotype, which is characterized by attenuated production of proinflammatory mediators, but enhanced secretion of anti-inflammatory mediators, such as IL-10, TGF- $\beta 1$, and prostaglandin $\mathrm{E}_{2}\left(\mathrm{PGE}_{2}\right)$. The M2-type designation regroups several populations of macrophages with different biochemistry and function, like wound-healing (M2a), hybrid (M2b), and regulatory (M2c) macrophages[114,124]. Concerning these different M2 macrophage subpopulations, PPAR $\gamma$ activation primes monocytes for differentiation into alternative M2 macrophages with anti-inflammatory properties[84]. In their study Bouhlel et al. demonstrated that in human atherosclerotic lesions, the expression of M2 markers (AMAC-1, CD36, CD206, IL-10) and PPAR $\gamma$ positively correlated. Interestingly, PPAR $\gamma$ activation in resting primary human monocytes did not induce the M2 phenotype, whereas PPAR $\gamma$ agonists being applied in combination with IL-4/IL-13 enhanced expression of M2 markers compared to controls treated only with IL-4/IL-13. In addition, M2 macrophages retain a high level of PPAR $\gamma$ expression[85]. Because macrophages are plastic cells, they can switch from an activated M1 phenotype to M2, and vice versa, upon specific signals[125]. In 2000, Li et al. provided evidence that the PPAR $\gamma$ agonists rosiglitazone and GW7845 strongly inhibited development of atherosclerosis in male LDL-R ${ }^{-/-}$mice[126]. The antiatherogenic effect in male mice correlated with impaired insulin sensitivity and decreased tissue expression of $\mathrm{TNF} \alpha$. Using the apolipoprotein $\mathrm{E}$ knockout $\left(\mathrm{ApoE}^{--}\right.$) mouse model, Chen et al. demonstrated a similar outcome in response to the TZD rosiglitazone, attenuating fatty streak formation and accordingly inhibiting atherosclerosis[127]. Studies elucidating the role of PPAR $\gamma$ in advanced atherosclerotic lesions in LDL- $\mathrm{R}^{--}$mice found that TZDs cannot reverse, but block, atherosclerosis progression[128] or sometimes even enhance atherosclerosis by increasing macrophage apoptosis and plaque necrosis[129]. A gene therapy approach by a recombinant adenovirus carrying mouse PPAR $\gamma$ cDNA provoking overexpression of PPAR $\gamma$ in $\mathrm{ApoE}^{--}$mice already suffering from atherosclerosis attenuated atherosclerotic lesions and stabilized atherosclerotic plaques[130]. This study suggests that PPAR $\gamma$ might offer a promising gene therapeutic target, improving atherosclerosis formation.

Taken together, the role of PPAR $\gamma$ in atherosclerosis seems mainly atheroprotective. Therefore, therapeutic approaches might focus on prolonged PPAR $\gamma$ activation or intervention with PPAR $\gamma$ downregulation. However, one should keep in mind that a main reason for atherosclerosis progression is the formation of the necrotic core in the intima, whose onset might be, at least in part, triggered by desensitized macrophages that are unable to remove the accumulating cellular debris completely[131,132]. Under these circumstances, activation of PPAR $\gamma$, enhancing an anti-inflammatory macrophages phenotype, might be even more deleterious. Therefore, further research is necessary to elucidate fully the time response of a provs. antiatherosclerotic role of PPAR $\gamma$ during atherosclerosis progression.

Apart from the three mentioned diseases, PPAR $\gamma$ is expressed in many other tissues/cells and, thus, is a possible therapeutic target in regulating other diseases. In part, preclinical studies using TZDs have been effective in several animal disease models. A brief overview is provided in Table 1. 
TABLE 1

Effects of TZD Treatments and PPAR $\gamma$ Gene Dosage on Rodent Models of Inflammation

\begin{tabular}{|c|c|c|c|c|}
\hline Disease & Model & Intervention & Effect & Refs. \\
\hline \multirow{3}{*}{$\begin{array}{l}\text { Experimental } \\
\text { autoimmune } \\
\text { encephalomyelitis }\end{array}$} & & $\begin{array}{l}\text { Wild type vs. } \\
\text { PPAR }^{+/-}\end{array}$ & $\uparrow$ Severity in PPAR $\gamma^{+/-}$mice & [133] \\
\hline & & PI, RO, GW & $\begin{array}{l}\downarrow \text { Incidence and severity in monophasic } \\
\text { disease }\end{array}$ & {$[134,135]$} \\
\hline & & TR & $\downarrow$ Severity & {$[136]$} \\
\hline \multirow[t]{6}{*}{ Colitis } & DSS & $\mathrm{TR}, \mathrm{RO}$ & $\downarrow$ Colonic inflammation & [137] \\
\hline & TNBS & $\begin{array}{l}\text { Wild type vs. } \\
\text { PPAR }^{+/-}\end{array}$ & $\begin{array}{l}\uparrow \text { Colonic inflammation in PPAR } \gamma^{+/-} \\
\text {mice }\end{array}$ & {$[24]$} \\
\hline & & TR, RO & $\downarrow$ Colonic inflammation & {$[24,138]$} \\
\hline & DSS/azoxymethane & TR & $\downarrow$ Colonic inflammation & [139] \\
\hline & DSS & $\begin{array}{l}\text { Wild type vs. } \\
\text { PPAR }^{+-}\end{array}$ & $\begin{array}{l}\uparrow \text { Colonic inflammation and mortality in } \\
\text { PPAR } \gamma^{+-} \text {mice }\end{array}$ & [140] \\
\hline & & $\mathrm{TR}, \mathrm{RO}, \mathrm{PI}$ & $\begin{array}{l}\downarrow \text { Colonic inflammation (only before } \\
\text { disease initiation) }\end{array}$ & \\
\hline \multirow[t]{3}{*}{ Arthritis } & $\mathrm{CIA}$ & RO & $\downarrow$ Incidence and severity & {$[141]$} \\
\hline & AIA-CFA & $\begin{array}{l}\text { Wild type vs. } \\
\text { PPAR } \gamma^{+-}\end{array}$ & $\uparrow$ Severity in PPAR $\gamma^{+/-}$mice & [142] \\
\hline & AIA-CFA & PI, RO & $\downarrow$ Inflammation & [143] \\
\hline \multirow[t]{2}{*}{ Obesity } & ob/ob & $\begin{array}{l}\text { Diet-induced } \\
\text { obesity }\end{array}$ & $\uparrow$ Adipose tissue inflammation & [144] \\
\hline & & $\mathrm{RO}$ & $\begin{array}{l}\downarrow \text { Macrophage infiltration; } \downarrow \text { adipose } \\
\text { tissue inflammation }\end{array}$ & \\
\hline \multirow[t]{2}{*}{ Airway inflammation } & TDI-induced asthma & $\begin{array}{l}\text { Ad-PPAR } \gamma, \mathrm{RO} \\
\mathrm{PI}\end{array}$ & $\downarrow$ Symptoms of asthma & [145] \\
\hline & $\begin{array}{l}\text { Murine asthma } \\
\text { LPS-induced neutrophilia } \\
\text { Pulmonary fibrosis }\end{array}$ & $\begin{array}{l}\mathrm{Cl}, \mathrm{RO}, \mathrm{PG}, \mathrm{Gl} \\
\mathrm{SB}\end{array}$ & $\begin{array}{l}\downarrow \text { Eosinphilic influx, mucus production, } \\
\text { serum IgE } \\
\downarrow \text { Neutrophila } \\
\downarrow \text { Edema, lung injury }\end{array}$ & [146] \\
\hline Pancreatitis & Cerulein-induced pancreatitis & $\mathrm{RO}$ & $\begin{array}{l}\downarrow \text { Pancreatic inflammation, neutrophil } \\
\text { inflitration }\end{array}$ & {$[147]$} \\
\hline Psoriasis & Epidermal hyperplasia & $\mathrm{Cl}, \mathrm{TR}$ & $\begin{array}{l}\downarrow \text { Epidermal keratinocyte proliferation; } \uparrow \\
\text { differentiation }\end{array}$ & {$[148]$} \\
\hline Acute inflammation & $\begin{array}{l}\text { Carrageenan-induced edema } \\
\text { or pleurisy }\end{array}$ & Ro & $\begin{array}{l}\downarrow \text { Paw edema, pleural exudate } \\
\text { formation, mononuclear cell infiltration, } \\
\text { histological injury }\end{array}$ & {$[149]$} \\
\hline
\end{tabular}

Abbreviations: Ad, adenovirus; AIA, adjuvant-induced arthritis; CFA, complete Freund's adjuvant; CI, ciglitazone; CIA, collageninduced arthritis; DSS, dextran sulfate sodium; GW, GW7845 ; ob/ob, leptin-deficient mice; PG, 15d-PGJ ; PI, pioglitazone; Ro, rosiglitazone; SB, SB219994; TDI, toluene diisocyanate; TNBS, 2,4,6-trinitrobenzene sulfonic acid; TR, troglitazone.

\section{CONCLUDING REMARKS}

It is hypothesized that the anti-inflammatory action of PPARs may explain the protective effects of these receptors in sepsis, atherosclerosis, cancer, and other inflammatory diseases (Fig. 2). However, emerging evidence for proinflammatory activities of activated PPARs is arising in light of new studies that associate PPAR $\gamma$ modulators with an increased incidence of both cardiovascular events in humans and sporadic formation of tumors in rodents. The antidiabetic TZDs are drugs that signal mainly via PPAR $\gamma$ and are used in clinical practice. A series of mechanistic studies revealed that TZDs, at clinically relevant concentrations, also bind and activate the transcriptional activity of PPAR $\delta$ [34]. Collectively, these studies suggest that the observed proinflammatory and potentially deleterious effect of PPAR $\gamma$ ligands may 


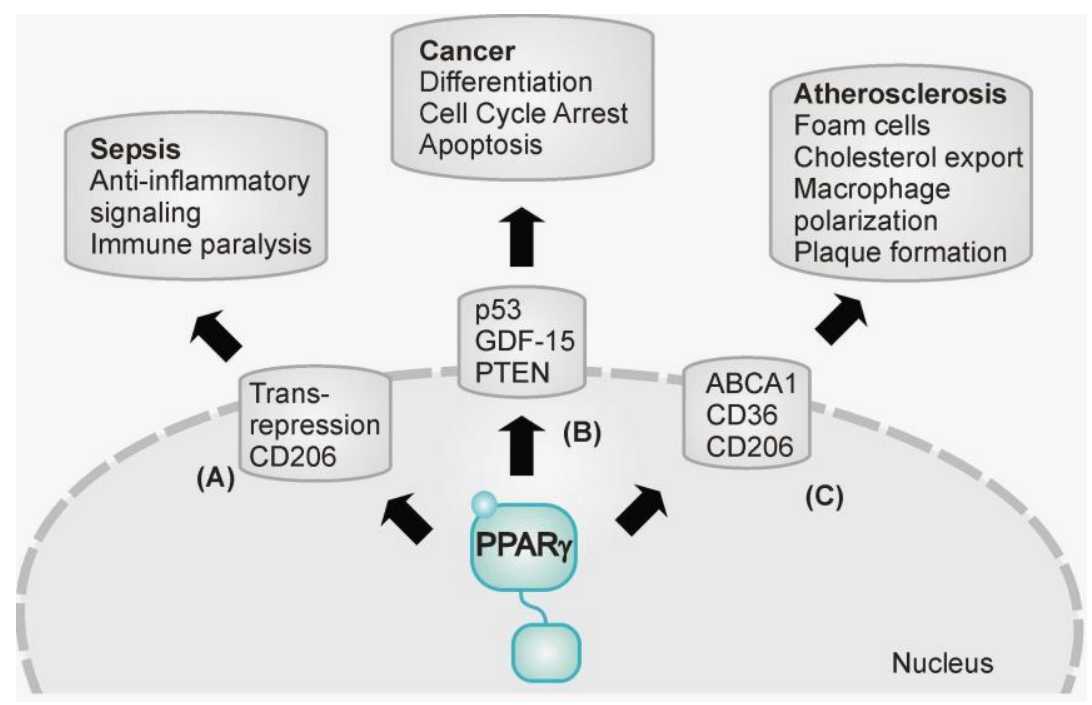

FIGURE 2. Summary of PPAR $\gamma$-dependent effects in sepsis, cancer, and atherosclerosis. (A) In sepsis, the role of PPAR $\gamma$ is controversial. Transrepression of proinflammatory signaling during the initial phase of sepsis attenuates overwhelming inflammation, but may provoke insufficient bacterial clearance. Immune paralysis characterized by monocyte/macrophage desensitization as well as lymphocyte apoptosis is caused, in part, by PPAR $\gamma$. Thus, PPAR $\gamma$ contributes to M2 macrophage polarization, for example, by induction of the M2 marker CD206 and repression of proinflammatory cytokine expression. Moreover, PPAR $\gamma$ seems to play an important role in lymphocyte apoptosis by a so-far-unidentified mechanism. (B) Cancer initiation and progression are inhibited by PPAR $\gamma$-mediated expression of the tumor suppressor $\mathrm{p} 53$, the antiproliferative operating phosphatase PTEN, and the cell cycle arresting GDF-15. (C) PPAR $\gamma$ activation is involved in atherosclerosis by inducing CD36 expression, increasing oxLDL uptake, consequently fostering foam cell formation and contributing to M2 macrophage polarization. This might be involved in plaque formation due to incomplete phagocytosis of apoptotic debris and concomitant generation of the necrotic core. However, PPAR $\gamma$-dependent induction of ATPbinding cassette transporters, such as ABCA1, provokes enhanced cholesterol export, thus counteracting atherosclerosis progression.

be mediated through an off-target effect on PPAR $\delta$. These studies highlight the need for PPAR modulators with increased receptor subtype specificity. Furthermore, they suggest that differences in systemic exposure and, consequently, in the activation of PPAR $\gamma$ and PPAR $\delta$ may explain why TZDs can exhibit both inflammatory and anti-inflammatory activities in humans[150]. Although their supposed carcinogenic or toxic effects have to be monitored carefully, PPARs are important therapeutic targets. Many valuable approaches are now under consideration. Cell type- or tissue-specific PPAR $\gamma$ knockout mice, or humanized mice carrying the human PPAR $\gamma$ gene, will help to improve the understanding of the various actions of PPAR $\gamma$ in major diseases. In addition, the development of selective PPAR modulators (SPPARMs), rather than PPAR full agonists, which retain most of the benefits while reducing the adverse effects of PPAR activation, is a promising approach. Moreover, antagonizing PPAR $\gamma$ might also be of therapeutic importance. For example, this might improve sepsis outcome by attenuating T-cell depletion, thus preventing immune paralysis. Dependent on the respective tumor type, PPAR $\gamma$ activation or antagonization might block tumor development and progression. Finally, there is a similar picture in atherosclerosis. In the initial phase, PPAR $\gamma$ activation might prevent inflammatory conditions in the vessel and/or intima, which will significantly delay/retard plaque formation. At a later point of time, antagonizing PPAR $\gamma$ might be more attractive in order to avoid deficient removal of apoptotic debris. For all these reasons, PPAR $\gamma$ is certainly a useful therapeutic target to be explored further in the context of major diseases, such as sepsis, cancer, and atherosclerosis[79]. 


\section{REFERENCES}

1. Abdelrahman, M., Sivarajah, A., and Thiemermann, C. (2005) Beneficial effects of PPAR-gamma ligands in ischemia-reperfusion injury, inflammation and shock. Cardiovasc. Res. 65, 772-781.

2. Pascual, G. and Glass, C.K. (2006) Nuclear receptors versus inflammation: mechanisms of transrepression. Trends Endocrinol. Metab. 17, 321-327.

3. Straus, D.S. and Glass, C.K. (2007) Anti-inflammatory actions of PPAR ligands: new insights on cellular and molecular mechanisms. Trends Immunol. 28, 551-558.

4. Farmer, S.R. (2006) Transcriptional control of adipocyte formation. Cell Metab. 4, 263-273.

5. Willson, T.M., Lambert, M.H., and Kliewer, S.A. (2001) Peroxisome proliferator-activated receptor gamma and metabolic disease. Annu. Rev. Biochem. 70, 341-367.

6. Lehrke, M. and Lazar, M.A. (2005) The many faces of PPARgamma. Cell 123, 993-999.

7. Szeles, L., Torocsik, D., and Nagy, L. (2007) PPARgamma in immunity and inflammation: cell types and diseases. Biochim. Biophys. Acta 1771, 1014-1030.

8. Li, M., Pascual, G., and Glass, C.K. (2000) Peroxisome proliferator-activated receptor gamma-dependent repression of the inducible nitric oxide synthase gene. Mol. Cell. Biol. 20, 4699-4707.

9. $\quad$ von Knethen, A., Soller, M., Tzieply, N., Weigert, A., Johann, A.M., Jennewein, C., Kohl, R., and Brune, B. (2007) PPARgamma1 attenuates cytosol to membrane translocation of PKCalpha to desensitize monocytes/macrophages. $J$. Cell Biol. 176, 681-694.

10. Ricote, M. and Glass, C.K. (2007) PPARs and molecular mechanisms of transrepression. Biochim. Biophys. Acta 1771, 926-935.

11. Chen, F., Wang, M., O'Connor, J.P., He, M., Tripathi, T., and Harrison, L.E. (2003) Phosphorylation of PPARgamma via active ERK1/2 leads to its physical association with p65 and inhibition of NF-kappabeta. J. Cell. Biochem. 90, 732-744.

12. Gupta, R.A., Polk, D.B., Krishna, U., Israel, D.A., Yan, F., DuBois, R.N., and Peek, R.M., Jr. (2001) Activation of peroxisome proliferator-activated receptor gamma suppresses nuclear factor kappa B-mediated apoptosis induced by Helicobacter pylori in gastric epithelial cells. J. Biol. Chem. 276, 31059-31066.

13. Wang, P., Anderson, P.O., Chen, S., Paulsson, K.M., Sjogren, H.O., and Li, S. (2001) Inhibition of the transcription factors $\mathrm{AP}-1$ and $\mathrm{NF}-\mathrm{kappaB}$ in $\mathrm{CD} 4 \mathrm{~T}$ cells by peroxisome proliferator-activated receptor gamma ligands. Int. Immunopharmacol. 1, 803-812.

14. Yang, X.Y., Wang, L.H., Chen, T., Hodge, D.R., Resau, J.H., DaSilva, L., and Farrar, W.L. (2000) Activation of human $\mathrm{T}$ lymphocytes is inhibited by peroxisome proliferator-activated receptor gamma (PPARgamma) agonists. PPARgamma co-association with transcription factor NFAT. J. Biol. Chem. 275, 4541-4544.

15. Subbaramaiah, K., Lin, D.T., Hart, J.C., and Dannenberg, A.J. (2001) Peroxisome proliferator-activated receptor gamma ligands suppress the transcriptional activation of cyclooxygenase-2. Evidence for involvement of activator protein-1 and CREB-binding protein/p300. J. Biol. Chem. 276, 12440-12448.

16. Shipley, J.M. and Waxman, D.J. (2003) Down-regulation of STAT5b transcriptional activity by ligand-activated peroxisome proliferator-activated receptor (PPAR) alpha and PPARgamma. Mol. Pharmacol. 64, 355-364.

17. Daynes, R.A. and Jones, D.C. (2002) Emerging roles of PPARs in inflammation and immunity. Nat. Rev. Immunol. 2, 748-759.

18. Ramos, Y.F., Hestand, M.S., Verlaan, M., Krabbendam, E., Ariyurek, Y., van Galen, M., van Dam, H., van Ommen, G.J., den Dunnen, J.T., Zantema, A., and t Hoen, P.A. (2010) Genome-wide assessment of differential roles for p300 and CBP in transcription regulation. Nucleic Acids Res. 38, 5396-5408.

19. Sahar, S., Reddy, M.A., Wong, C., Meng, L., Wang, M., and Natarajan, R. (2007) Cooperation of SRC-1 and p300 with NF-kappaB and CREB in angiotensin II-induced IL-6 expression in vascular smooth muscle cells. Arterioscler. Thromb. Vasc. Biol. 27, 1528-1534.

20. Pascual, G., Fong, A.L., Ogawa, S., Gamliel, A., Li, A.C., Perissi, V., Rose, D.W., Willson, T.M., Rosenfeld, M.G., and Glass, C.K. (2005) A SUMOylation-dependent pathway mediates transrepression of inflammatory response genes by PPAR-gamma. Nature 437, 759-763.

21. Jennewein, C., Kuhn, A.M., Schmidt, M.V., Meilladec-Jullig, V., von Knethen, A., Gonzalez, F.J., and Brune, B. (2008) Sumoylation of peroxisome proliferator-activated receptor gamma by apoptotic cells prevents lipopolysaccharide-induced NCoR removal from kappaB binding sites mediating transrepression of proinflammatory cytokines. J. Immunol. 181, 5646-5652.

22. Park, J.Y., Bae, M.A., Cheon, H.G., Kim, S.S., Hong, J.M., Kim, T.H., Choi, J.Y., Kim, S.H., Lim, J., Choi, C.H., Shin, H.I., Kim, S.Y., and Park, E.K. (2009) A novel PPARgamma agonist, KR62776, suppresses RANKL-induced osteoclast differentiation and activity by inhibiting MAP kinase pathways. Biochem. Biophys. Res. Commun. 378, 645-649.

23. Ji, H., Wang, H., Zhang, F., Li, X., Xiang, L., and Aiguo, S. (2010) PPARgamma agonist pioglitazone inhibits microglia inflammation by blocking p38 mitogen-activated protein kinase signaling pathways. Inflamm. Res. 59, 921-929. 
24. Desreumaux, P., Dubuquoy, L., Nutten, S., Peuchmaur, M., Englaro, W., Schoonjans, K., Derijard, B., Desvergne, B., Wahli, W., Chambon, P., Leibowitz, M.D., Colombel, J.F., and Auwerx, J. (2001) Attenuation of colon inflammation through activators of the retinoid X receptor $(\mathrm{RXR}) /$ peroxisome proliferator-activated receptor gamma (PPARgamma) heterodimer. A basis for new therapeutic strategies. J. Exp. Med. 193, 827-838.

25. Johann, A.M., von Knethen, A., Lindemann, D., and Brune, B. (2006) Recognition of apoptotic cells by macrophages activates the peroxisome proliferator-activated receptor-gamma and attenuates the oxidative burst. Cell Death Differ. 13, 1533-1540.

26. von Knethen, A., Tzieply, N., Jennewein, C., and Brune, B. (2010) Casein-kinase-II-dependent phosphorylation of PPARgamma provokes CRM1-mediated shuttling of PPARgamma from the nucleus to the cytosol. J. Cell Sci. 123, 192-201.

27. Clark, R.B., Bishop-Bailey, D., Estrada-Hernandez, T., Hla, T., Puddington, L., and Padula, S.J. (2000) The nuclear receptor PPAR gamma and immunoregulation: PPAR gamma mediates inhibition of helper T cell responses. $J$. Immunol. 164, 1364-1371.

28. Harris, S.G. and Phipps, R.P. (2001) The nuclear receptor PPAR gamma is expressed by mouse T lymphocytes and PPAR gamma agonists induce apoptosis. Eur. J. Immunol. 31, 1098-1105.

29. Kim, E.J., Cho, D., Hwang, S.Y., and Kim, T.S. (2001) Interleukin-2 fusion protein with anti-CD3 single-chain Fv (sFv) selectively protects T cells from dexamethasone-induced apoptosis. Vaccine 20, 608-615.

30. Cunard, R., Ricote, M., DiCampli, D., Archer, D.C., Kahn, D.A., Glass, C.K., and Kelly, C.J. (2002) Regulation of cytokine expression by ligands of peroxisome proliferator activated receptors. J. Immunol. 168, 2795-2802.

31. Schmitz, J., Thiel, A., Kuhn, R., Rajewsky, K., Muller, W., Assenmacher, M., and Radbruch, A. (1994) Induction of interleukin 4 (IL-4) expression in T helper (Th) cells is not dependent on IL-4 from non-Th cells. J. Exp. Med. 179, 1349-1353.

32. Yang, X.Y., Wang, L.H., Mihalic, K., Xiao, W., Chen, T., Li, P., Wahl, L.M., and Farrar, W.L. (2002) Interleukin (IL)-4 indirectly suppresses IL-2 production by human T lymphocytes via peroxisome proliferator-activated receptor gamma activated by macrophage-derived 12/15-lipoxygenase ligands. J. Biol. Chem. 277, 3973-3978.

33. Chtanova, T., Kemp, R.A., Sutherland, A.P., Ronchese, F., and Mackay, C.R. (2001) Gene microarrays reveal extensive differential gene expression in both CD4(+) and CD8(+) type 1 and type 2 T cells. J. Immunol. 167, 30573063.

34. Welch, J.S., Ricote, M., Akiyama, T.E., Gonzalez, F.J., and Glass, C.K. (2003) PPARgamma and PPARdelta negatively regulate specific subsets of lipopolysaccharide and IFN-gamma target genes in macrophages. Proc. Natl. Acad. Sci. U. S. A. 100, 6712-6717.

35. Klotz, L., Burgdorf, S., Dani, I., Saijo, K., Flossdorf, J., Hucke, S., Alferink, J., Nowak, N., Beyer, M., Mayer, G., Langhans, B., Klockgether, T., Waisman, A., Eberl, G., Schultze, J., Famulok, M., Kolanus, W., Glass, C., Kurts, C., and Knolle, P.A. (2009) The nuclear receptor PPAR gamma selectively inhibits Th17 differentiation in a T cellintrinsic fashion and suppresses CNS autoimmunity. J. Exp. Med. 206, 2079-2089.

36. Chung, S.W., Kang, B.Y., Kim, S.H., Pak, Y.K., Cho, D., Trinchieri, G., and Kim, T.S. (2000) Oxidized low density lipoprotein inhibits interleukin-12 production in lipopolysaccharide-activated mouse macrophages via direct interactions between peroxisome proliferator-activated receptor-gamma and nuclear factor-kappa B. J. Biol. Chem. 275, 32681-32687.

37. Zapolska-Downar, D. and Naruszewicz, M. (2009) Propionate reduces the cytokine-induced VCAM-1 and ICAM-1 expression by inhibiting nuclear factor-kappa B (NF-kappaB) activation. J. Physiol. Pharmacol. 60, 123-131.

38. Lin, T.H., Yang, R.S., Tang, C.H., Lin, C.P., and Fu, W.M. (2007) PPARgamma inhibits osteogenesis via the downregulation of the expression of COX-2 and iNOS in rats. Bone 41, 562-574.

39. Liu, J.J., Liu, P.Q., Lin, D.J., Xiao, R.Z., Huang, M., Li, X.D., He, Y., and Huang, R.W. (2007) Downregulation of cyclooxygenase-2 expression and activation of caspase-3 are involved in peroxisome proliferator-activated receptorgamma agonists induced apoptosis in human monocyte leukemia cells in vitro. Ann. Hematol. 86, 173-183.

40. Kaplan, J.M., Cook, J.A., Hake, P.W., O'Connor, M., Burroughs, T.J., and Zingarelli, B. (2005) 15-Deoxydelta(12,14)-prostaglandin J(2) (15D-PGJ(2)), a peroxisome proliferator activated receptor gamma ligand, reduces tissue leukosequestration and mortality in endotoxic shock. Shock 24, 59-65.

41. Lee, K.J., Ha, E.S., Kim, M.K., Lee, S.H., Suh, J.S., Lee, S.H., Park, K.H., Park, J.H., Kim, D.J., Kang, D., Kim, B.C., Jeoung, D., Kim, Y.K., Kim, H.D., and Hahn, J.H. (2008) CD36 signaling inhibits the translation of heat shock protein 70 induced by oxidized low density lipoprotein through activation of peroxisome proliferators-activated receptor gamma. Exp. Mol. Med. 40, 658-668.

42. Matsui, H., Asou, H., and Inaba, T. (2007) Cytokines direct the regulation of Bim mRNA stability by heat-shock cognate protein 70. Mol. Cell 25, 99-112.

43. Kaplan, J., Cook, J.A., O'Connor, M., and Zingarelli, B. (2007) Peroxisome proliferator-activated receptor gamma is required for the inhibitory effect of ciglitazone but not 15-deoxy-delta 12,14-prostaglandin J2 on the NFkappaB pathway in human endothelial cells. Shock 28, 722-726.

44. Straus, D.S., Pascual, G., Li, M., Welch, J.S., Ricote, M., Hsiang, C.H., Sengchanthalangsy, L.L., Ghosh, G., and Glass, C.K. (2000) 15-Deoxy-delta 12,14-prostaglandin J2 inhibits multiple steps in the NF-kappa B signaling pathway. Proc. Natl. Acad. Sci. U. S. A. 97, 4844-4849. 
45. Ayala, A., Wesche-Soldato, D.E., Perl, M., Lomas-Neira, J.L., Swan, R., and Chung, C.S. (2007) Blockade of apoptosis as a rational therapeutic strategy for the treatment of sepsis. Novartis Found. Symp. 280, 37-49; discussion 49-52, 160-164.

46. Riedemann, N.C., Guo, R.F., and Ward, P.A. (2003) Novel strategies for the treatment of sepsis. Nat. Med. 9, 517524.

47. Hotchkiss, R.S., Chang, K.C., Swanson, P.E., Tinsley, K.W., Hui, J.J., Klender, P., Xanthoudakis, S., Roy, S., Black, C., Grimm, E., Aspiotis, R., Han, Y., Nicholson, D.W., and Karl, I.E. (2000) Caspase inhibitors improve survival in sepsis: a critical role of the lymphocyte. Nat. Immunol. 1, 496-501.

48. Hotchkiss, R.S., Coopersmith, C.M., and Karl, I.E. (2005) Prevention of lymphocyte apoptosis--a potential treatment of sepsis? Clin. Infect. Dis. 41(Suppl 7), S465-469.

49. Hotchkiss, R.S., Coopersmith, C.M., McDunn, J.E., and Ferguson, T.A. (2009) The sepsis seesaw: tilting toward immunosuppression. Nat. Med. 15, 496-497.

50. Hotchkiss, R.S., Tinsley, K.W., Swanson, P.E., Chang, K.C., Cobb, J.P., Buchman, T.G., Korsmeyer, S.J., and Karl, I.E. (1999) Prevention of lymphocyte cell death in sepsis improves survival in mice. Proc. Natl. Acad. Sci. U. S. A. 96, 14541-14546.

51. Hotchkiss, R.S., Swanson, P.E., Knudson, C.M., Chang, K.C., Cobb, J.P., Osborne, D.F., Zollner, K.M., Buchman, T.G., Korsmeyer, S.J., and Karl, I.E. (1999) Overexpression of Bcl-2 in transgenic mice decreases apoptosis and improves survival in sepsis. J. Immunol. 162, 4148-4156.

52. Peck-Palmer, O.M., Unsinger, J., Chang, K.C., McDonough, J.S., Perlman, H., McDunn, J.E., and Hotchkiss, R.S. (2009) Modulation of the Bcl-2 family blocks sepsis-induced depletion of dendritic cells and macrophages. Shock 31, 359-366.

53. Wagner, T.H., Drewry, A.M., Macmillan, S., Dunne, W.M., Chang, K.C., Karl, I.E., Hotchkiss, R.S., and Cobb, J.P. (2007) Surviving sepsis: bcl-2 overexpression modulates splenocyte transcriptional responses in vivo. Am. J. Physiol. Regul. Integr. Comp. Physiol. 292, R1751-1759.

54. Brahmamdam, P., Watanabe, E., Unsinger, J., Chang, K.C., Schierding, W., Hoekzema, A.S., Zhou, T.T., McDonough, J.S., Holemon, H., Heidel, J.D., Coopersmith, C.M., McDunn, J.E., and Hotchkiss, R.S. (2009) Targeted delivery of siRNA to cell death proteins in sepsis. Shock 32, 131-139.

55. Hotchkiss, R.S., McConnell, K.W., Bullok, K., Davis, C.G., Chang, K.C., Schwulst, S.J., Dunne, J.C., Dietz, G.P., Bahr, M., McDunn, J.E., Karl, I.E., Wagner, T.H., Cobb, J.P., Coopersmith, C.M., and Piwnica-Worms, D. (2006) TAT-BH4 and TAT-Bcl-xL peptides protect against sepsis-induced lymphocyte apoptosis in vivo. J. Immunol. 176, 5471-5477.

56. Schwulst, S.J., Muenzer, J.T., Peck-Palmer, O.M., Chang, K.C., Davis, C.G., McDonough, J.S., Osborne, D.F., Walton, A.H., Unsinger, J., McDunn, J.E., and Hotchkiss, R.S. (2008) Bim siRNA decreases lymphocyte apoptosis and improves survival in sepsis. Shock 30, 127-134.

57. Strasser, A. and Pellegrini, M. (2004) T-lymphocyte death during shutdown of an immune response. Trends Immunol. 25, 610-615.

58. Weber, S.U., Schewe, J.C., Lehmann, L.E., Muller, S., Book, M., Klaschik, S., Hoeft, A., and Stuber, F. (2008) Induction of Bim and Bid gene expression during accelerated apoptosis in severe sepsis. Crit. Care 12, R128.

59. Soller, M., Tautenhahn, A., Brune, B., Zacharowski, K., John, S., Link, H., and von Knethen, A. (2006) Peroxisome proliferator-activated receptor gamma contributes to T lymphocyte apoptosis during sepsis. J. Leukoc. Biol. 79, 235243.

60. Tautenhahn, A., Brune, B., and von Knethen, A. (2003) Activation-induced PPARgamma expression sensitizes primary human T cells toward apoptosis. J. Leukoc. Biol. 73, 665-672.

61. Patel, L., Pass, I., Coxon, P., Downes, C.P., Smith, S.A., and Macphee, C.H. (2001) Tumor suppressor and antiinflammatory actions of PPARgamma agonists are mediated via upregulation of PTEN. Curr. Biol. 11, 764-768.

62. Bonofiglio, D., Gabriele, S., Aquila, S., Catalano, S., Gentile, M., Middea, E., Giordano, F., and Ando, S. (2005) Estrogen receptor alpha binds to peroxisome proliferator-activated receptor response element and negatively interferes with peroxisome proliferator-activated receptor gamma signaling in breast cancer cells. Clin. Cancer Res. 11, 6139-6147.

63. Teresi, R.E., Shaiu, C.W., Chen, C.S., Chatterjee, V.K., Waite, K.A., and Eng, C. (2006) Increased PTEN expression due to transcriptional activation of PPARgamma by lovastatin and rRosiglitazone. Int. J. Cancer 118, 2390-2398.

64. Bonofiglio, D., Aquila, S., Catalano, S., Gabriele, S., Belmonte, M., Middea, E., Qi, H., Morelli, C., Gentile, M., Maggiolini, M., and Ando, S. (2006) Peroxisome proliferator-activated receptor-gamma activates p53 gene promoter binding to the nuclear factor-kappaB sequence in human MCF7 breast cancer cells. Mol. Endocrinol. 20, 3083-3092.

65. Zaytseva, Y.Y., Wang, X., Southard, R.C., Wallis, N.K., and Kilgore, M.W. (2008) Down-regulation of PPARgamma1 suppresses cell growth and induces apoptosis in MCF-7 breast cancer cells. Mol. Cancer 7, 90.

66. Wang, X., Southard, R.C., Allred, C.D., Talbert, D.R., Wilson, M.E., and Kilgore, M.W. (2008) MAZ drives tumorspecific expression of PPAR gamma 1 in breast cancer cells. Breast Cancer Res. Treat. 111, 103-111.

67. Wang, X., Southard, R.C., and Kilgore, M.W. (2004) The increased expression of peroxisome proliferator-activated receptor-gamma1 in human breast cancer is mediated by selective promoter usage. Cancer Res. 64, 5592-5596. 
68. Yu, J., Shen, B., Chu, E.S., Teoh, N., Cheung, K.F., Wu, C.W., Wang, S., Lam, C.N., Feng, H., Zhao, J., Cheng, A.S., To, K.F., Chan, H.L., and Sung, J.J. (2010) Inhibitory role of peroxisome proliferator-activated receptor gamma in hepatocarcinogenesis in mice and in vitro. Hepatology 51, 2008-2019.

69. Baek, S.J., Kim, J.S., Jackson, F.R., Eling, T.E., McEntee, M.F., and Lee, S.H. (2004) Epicatechin gallate-induced expression of NAG-1 is associated with growth inhibition and apoptosis in colon cancer cells. Carcinogenesis $\mathbf{2 5}$, 2425-2432.

70. $\quad$ Chen, Y.L., Lin, P.C., Chen, S.P., Lin, C.C., Tsai, N.M., Cheng, Y.L., Chang, W.L., Lin, S.Z., and Harn, H.J. (2007) Activation of nonsteroidal anti-inflammatory drug-activated gene-1 via extracellular signal-regulated kinase $1 / 2$ mitogen-activated protein kinase revealed a isochaihulactone-triggered apoptotic pathway in human lung cancer A549 cells. J. Pharmacol. Exp. Ther. 323, 746-756.

71. Liu, T., Bauskin, A.R., Zaunders, J., Brown, D.A., Pankhurst, S., Russell, P.J., and Breit, S.N. (2003) Macrophage inhibitory cytokine 1 reduces cell adhesion and induces apoptosis in prostate cancer cells. Cancer Res. 63, 50345040.

72. Kroll, T.G., Sarraf, P., Pecciarini, L., Chen, C.J., Mueller, E., Spiegelman, B.M., and Fletcher, J.A. (2000) PAX8PPARgammal fusion oncogene in human thyroid carcinoma [corrected]. Science 289, 1357-1360.

73. Eberhardt, N.L., Grebe, S.K., McIver, B., and Reddi, H.V. (2010) The role of the PAX8/PPARgamma fusion oncogene in the pathogenesis of follicular thyroid cancer. Mol. Cell. Endocrinol. 321, 50-56.

74. Lui, W.O., Foukakis, T., Liden, J., Thoppe, S.R., Dwight, T., Hoog, A., Zedenius, J., Wallin, G., Reimers, M., and Larsson, C. (2005) Expression profiling reveals a distinct transcription signature in follicular thyroid carcinomas with a PAX8-PPAR(gamma) fusion oncogene. Oncogene 24, 1467-1476.

75. Inamoto, T., Shah, J.B., and Kamat, A.M. (2009) Friend or foe? Role of peroxisome proliferator-activated receptorgamma in human bladder cancer. Urol. Oncol. 27, 585-591.

76. Kang, D.W., Choi, C.H., Park, J.Y., Kang, S.K., and Kim, Y.K. (2008) Ciglitazone induces caspase-independent apoptosis through down-regulation of XIAP and survivin in human glioma cells. Neurochem. Res. 33, 551-561.

77. Dranoff, G. (2004) Cytokines in cancer pathogenesis and cancer therapy. Nat. Rev. Cancer 4, 11-22.

78. Lin, W.W. and Karin, M. (2007) A cytokine-mediated link between innate immunity, inflammation, and cancer. $J$. Clin. Invest. 117, 1175-1183.

79. Michalik, L. and Wahli, W. (2008) PPARs mediate lipid signaling in inflammation and cancer. PPAR Res. 2008, 134059.

80. Karin, M. (2008) The IkappaB kinase - a bridge between inflammation and cancer. Cell Res. 18, 334-342.

81. Van Ginderachter, J.A., Movahedi, K., Van den Bossche, J., and De Baetselier, P. (2008) Macrophages, PPARs, and cancer. PPAR Res. 2008, 169414.

82. Solinas, G., Germano, G., Mantovani, A., and Allavena, P. (2009) Tumor-associated macrophages (TAM) as major players of the cancer-related inflammation. J. Leukoc. Biol. 86, 1065-1073.

83. Fauconnet, S., Lascombe, I., Chabannes, E., Adessi, G.L., Desvergne, B., Wahli, W., and Bittard, H. (2002) Differential regulation of vascular endothelial growth factor expression by peroxisome proliferator-activated receptors in bladder cancer cells. J. Biol. Chem. 277, 23534-23543.

84. Bouhlel, M.A., Derudas, B., Rigamonti, E., Dievart, R., Brozek, J., Haulon, S., Zawadzki, C., Jude, B., Torpier, G., Marx, N., Staels, B., and Chinetti-Gbaguidi, G. (2007) PPARgamma activation primes human monocytes into alternative M2 macrophages with anti-inflammatory properties. Cell Metab. 6, 137-143.

85. Odegaard, J.I., Ricardo-Gonzalez, R.R., Goforth, M.H., Morel, C.R., Subramanian, V., Mukundan, L., Red Eagle, A., Vats, D., Brombacher, F., Ferrante, A.W., and Chawla, A. (2007) Macrophage-specific PPARgamma controls alternative activation and improves insulin resistance. Nature 447, 1116-1120.

86. Olefsky, J.M. and Glass, C.K. (2010) Macrophages, inflammation, and insulin resistance. Annu. Rev. Physiol. 72, 219-246.

87. Van Ginderachter, J.A., Meerschaut, S., Liu, Y., Brys, L., De Groeve, K., Hassanzadeh Ghassabeh, G., Raes, G., and De Baetselier, P. (2006) Peroxisome proliferator-activated receptor gamma (PPARgamma) ligands reverse CTL suppression by alternatively activated (M2) macrophages in cancer. Blood 108, 525-535.

88. Shah, Y.M., Morimura, K., and Gonzalez, F.J. (2007) Expression of peroxisome proliferator-activated receptorgamma in macrophage suppresses experimentally induced colitis. Am. J. Physiol. Gastrointest. Liver Physiol. 292, G657-666.

89. Wei, S., Kulp, S.K., and Chen, C.S. (2010) Energy restriction as an antitumor target of thiazolidinediones. J. Biol. Chem. 285, 9780-9791.

90. Galli, A., Ceni, E., Mello, T., Polvani, S., Tarocchi, M., Buccoliero, F., Lisi, F., Cioni, L., Ottanelli, B., Foresta, V., Mastrobuoni, G., Moneti, G., Pieraccini, G., Surrenti, C., and Milani, S. (2010) Thiazolidinediones inhibit hepatocarcinogenesis in hepatitis B virus-transgenic mice by peroxisome proliferator-activated receptor gammaindependent regulation of nucleophosmin. Hepatology 52, 493-505.

91. Galli, A., Ceni, E., Crabb, D.W., Mello, T., Salzano, R., Grappone, C., Milani, S., Surrenti, E., Surrenti, C., and Casini, A. (2004) Antidiabetic thiazolidinediones inhibit invasiveness of pancreatic cancer cells via PPARgamma independent mechanisms. Gut 53, 1688-1697. 
92. Ricote, M., Valledor, A.F., and Glass, C.K. (2004) Decoding transcriptional programs regulated by PPARs and LXRs in the macrophage: effects on lipid homeostasis, inflammation, and atherosclerosis. Arterioscler. Thromb. Vasc. Biol. 24, 230-239.

93. Roberts, A.W., Thomas, A., Rees, A., and Evans, M. (2003) Peroxisome proliferator-activated receptor-gamma agonists in atherosclerosis: current evidence and future directions. Curr. Opin. Lipidol. 14, 567-573.

94. Yki-Jarvinen, H. (2004) Thiazolidinediones. N. Engl. J. Med. 351, 1106-1118.

95. Wang, M. and Tafuri, S. (2003) Modulation of PPARgamma activity with pharmaceutical agents: treatment of insulin resistance and atherosclerosis. J. Cell Biochem. 89, 38-47.

96. Kaul, S., Bolger, A.F., Herrington, D., Giugliano, R.P., and Eckel, R.H. (2010) Thiazolidinedione drugs and cardiovascular risks: a science advisory from the American Heart Association and American College of Cardiology Foundation. Circulation 121, 1868-1877.

97. Langenfeld, M.R., Forst, T., Hohberg, C., Kann, P., Lubben, G., Konrad, T., Fullert, S.D., Sachara, C., and Pfutzner, A. (2005) Pioglitazone decreases carotid intima-media thickness independently of glycemic control in patients with type 2 diabetes mellitus: results from a controlled randomized study. Circulation 111, 2525-2531.

98. Li, D., Chen, K., Sinha, N., Zhang, X., Wang, Y., Sinha, A.K., Romeo, F., and Mehta, J.L. (2005) The effects of PPAR-gamma ligand pioglitazone on platelet aggregation and arterial thrombus formation. Cardiovasc. Res. 65 , 907-912.

99. Derosa, G., Cicero, A.F., Gaddi, A., Ragonesi, P.D., Piccinni, M.N., Fogari, E., Salvadeo, S., Ciccarelli, L., and Fogari, R. (2005) A comparison of the effects of pioglitazone and rosiglitazone combined with glimepiride on prothrombotic state in type 2 diabetic patients with the metabolic syndrome. Diabetes Res. Clin. Pract. 69, 5-13.

100. Marx, N., Walcher, D., Ivanova, N., Rautzenberg, K., Jung, A., Friedl, R., Hombach, V., de Caterina, R., Basta, G., Wautier, M.P., and Wautiers, J.L. (2004) Thiazolidinediones reduce endothelial expression of receptors for advanced glycation end products. Diabetes 53, 2662-2668.

101. Majuri, A., Santaniemi, M., Rautio, K., Kunnari, A., Vartiainen, J., Ruokonen, A., Kesaniemi, Y.A., Tapanainen, J.S., Ukkola, O., and Morin-Papunen, L. (2007) Rosiglitazone treatment increases plasma levels of adiponectin and decreases levels of resistin in overweight women with PCOS: a randomized placebo-controlled study. Eur. J. Endocrinol. 156, 263-269.

102. Wang, T.D., Chen, W.J., Cheng, W.C., Lin, J.W., Chen, M.F., and Lee, Y.T. (2006) Relation of improvement in endothelium-dependent flow-mediated vasodilation after rosiglitazone to changes in asymmetric dimethylarginine, endothelin-1, and C-reactive protein in nondiabetic patients with the metabolic syndrome. Am. J. Cardiol. 98, 10571062.

103. Szapary, P.O., Bloedon, L.T., Samaha, F.F., Duffy, D., Wolfe, M.L., Soffer, D., Reilly, M.P., Chittams, J., and Rader, D.J. (2006) Effects of pioglitazone on lipoproteins, inflammatory markers, and adipokines in nondiabetic patients with metabolic syndrome. Arterioscler. Thromb. Vasc. Biol. 26, 182-188.

104. Haffner, S.M., Greenberg, A.S., Weston, W.M., Chen, H., Williams, K., and Freed, M.I. (2002) Effect of rosiglitazone treatment on nontraditional markers of cardiovascular disease in patients with type 2 diabetes mellitus. Circulation 106, 679-684.

105. Ross, R. (1999) Atherosclerosis--an inflammatory disease. N. Engl. J. Med. 340, 115-126.

106. Collins, A.R., Meehan, W.P., Kintscher, U., Jackson, S., Wakino, S., Noh, G., Palinski, W., Hsueh, W.A., and Law, R.E. (2001) Troglitazone inhibits formation of early atherosclerotic lesions in diabetic and nondiabetic low density lipoprotein receptor-deficient mice. Arterioscler. Thromb. Vasc. Biol. 21, 365-371.

107. Babaev, V.R., Yancey, P.G., Ryzhov, S.V., Kon, V., Breyer, M.D., Magnuson, M.A., Fazio, S., and Linton, M.F. (2005) Conditional knockout of macrophage PPARgamma increases atherosclerosis in C57BL/6 and low-density lipoprotein receptor-deficient mice. Arterioscler. Thromb. Vasc. Biol. 25, 1647-1653.

108. Woollard, K.J. and Geissmann, F. (2010) Monocytes in atherosclerosis: subsets and functions. Nat. Rev. Cardiol. 7 , 77-86.

109. Galkina, E. and Ley, K. (2009) Immune and inflammatory mechanisms of atherosclerosis (*). Annu. Rev. Immunol. 27, 165-197.

110. Moore, K.J., Rosen, E.D., Fitzgerald, M.L., Randow, F., Andersson, L.P., Altshuler, D., Milstone, D.S., Mortensen, R.M., Spiegelman, B.M., and Freeman, M.W. (2001) The role of PPAR-gamma in macrophage differentiation and cholesterol uptake. Nat. Med. 7, 41-47.

111. Chinetti, G., Lestavel, S., Bocher, V., Remaley, A.T., Neve, B., Torra, I.P., Teissier, E., Minnich, A., Jaye, M., Duverger, N., Brewer, H.B., Fruchart, J.C., Clavey, V., and Staels, B. (2001) PPAR-alpha and PPAR-gamma activators induce cholesterol removal from human macrophage foam cells through stimulation of the ABCA1 pathway. Nat. Med. 7, 53-58.

112. Akiyama, T.E., Sakai, S., Lambert, G., Nicol, C.J., Matsusue, K., Pimprale, S., Lee, Y.H., Ricote, M., Glass, C.K., Brewer, H.B., Jr., and Gonzalez, F.J. (2002) Conditional disruption of the peroxisome proliferator-activated receptor gamma gene in mice results in lowered expression of ABCA1, ABCG1, and apoE in macrophages and reduced cholesterol efflux. Mol. Cell. Biol. 22, 2607-2619.

113. Chawla, A., Barak, Y., Nagy, L., Liao, D., Tontonoz, P., and Evans, R.M. (2001) PPAR-gamma dependent and independent effects on macrophage-gene expression in lipid metabolism and inflammation. Nat. Med. 7, 48-52. 
114. Mosser, D.M. and Edwards, J.P. (2008) Exploring the full spectrum of macrophage activation. Nat. Rev. Immunol. 8, 958-969.

115. Gordon, S. (2003) Alternative activation of macrophages. Nat. Rev. Immunol. 3, 23-35.

116. Edwards, J.P., Zhang, X., Frauwirth, K.A., and Mosser, D.M. (2006) Biochemical and functional characterization of three activated macrophage populations. J. Leukoc. Biol. 80, 1298-1307.

117. Mackaness, G.B. (1964) The immunological basis of acquired cellular resistance. J. Exp. Med. 120, $105-120$.

118. Murray, H.W. (2008) Accelerated control of visceral Leishmania donovani infection in interleukin-6-deficient mice. Infect. Immun. 76, 4088-4091.

119. Jennewein, C., von Knethen, A., Schmid, T., and Brune, B. (2010) MicroRNA-27b contributes to lipopolysaccharide-mediated peroxisome proliferator-activated receptor gamma (PPARgamma) mRNA destabilization. J. Biol. Chem. 285, 11846-11853.

120. Necela, B.M., Su, W., and Thompson, E.A. (2008) Toll-like receptor 4 mediates cross-talk between peroxisome proliferator-activated receptor gamma and nuclear factor-kappaB in macrophages. Immunology 125, 344-358.

121. Zhou, M., Wu, R., Dong, W., Jacob, A., and Wang, P. (2008) Endotoxin downregulates peroxisome proliferatoractivated receptor-gamma via the increase in TNF-alpha release. Am. J. Physiol. Regul. Integr. Comp. Physiol. 294, R84-92.

122. Mendes Sdos, S., Candi, A., Vansteenbrugge, M., Pignon, M.R., Bult, H., Boudjeltia, K.Z., Munaut, C., and Raes, M. (2009) Microarray analyses of the effects of NF-kappaB or PI3K pathway inhibitors on the LPS-induced gene expression profile in RAW264.7 cells: synergistic effects of rapamycin on LPS-induced MMP9-overexpression. Cell. Signal. 21, 1109-1122.

123. von Knethen, A.A. and Brune, B. (2001) Delayed activation of PPARgamma by LPS and IFN-gamma attenuates the oxidative burst in macrophages. FASEB J. 15, 535-544.

124. Mantovani, A., Allavena, P., Sozzani, S., Vecchi, A., Locati, M., and Sica, A. (2004) Chemokines in the recruitment and shaping of the leukocyte infiltrate of tumors. Semin. Cancer Biol. 14, 155-160.

125. Porcheray, F., Viaud, S., Rimaniol, A.C., Leone, C., Samah, B., Dereuddre-Bosquet, N., Dormont, D., and Gras, G. (2005) Macrophage activation switching: an asset for the resolution of inflammation. Clin. Exp. Immunol. 142, 481489.

126. Li, A.C., Brown, K.K., Silvestre, M.J., Willson, T.M., Palinski, W., and Glass, C.K. (2000) Peroxisome proliferatoractivated receptor gamma ligands inhibit development of atherosclerosis in LDL receptor-deficient mice. J. Clin. Invest. 106, 523-531.

127. Chen, Z., Ishibashi, S., Perrey, S., Osuga, J., Gotoda, T., Kitamine, T., Tamura, Y., Okazaki, H., Yahagi, N., Iizuka, Y., Shionoiri, F., Ohashi, K., Harada, K., Shimano, H., Nagai, R., and Yamada, N. (2001) Troglitazone inhibits atherosclerosis in apolipoprotein E-knockout mice: pleiotropic effects on CD36 expression and HDL. Arterioscler. Thromb. Vasc. Biol. 21, 372-377.

128. Nakaya, H., Summers, B.D., Nicholson, A.C., Gotto, A.M., Jr., Hajjar, D.P., and Han, J. (2009) Atherosclerosis in LDLR-knockout mice is inhibited, but not reversed, by the PPARgamma ligand pioglitazone. Am. J. Pathol. 174, 2007-2014.

129. Thorp, E., Kuriakose, G., Shah, Y.M., Gonzalez, F.J., and Tabas, I. (2007) Pioglitazone increases macrophage apoptosis and plaque necrosis in advanced atherosclerotic lesions of nondiabetic low-density lipoprotein receptornull mice. Circulation 116, 2182-2190.

130. Hu, Q., Zhang, X.J., Zhang, C., Zhao, Y.X., He, H., Liu, C.X., Feng, J.B., Jiang, H., Yang, F.L., Zhang, C.X., and Zhang, Y. (2008) Peroxisome proliferator-activated receptor-gamma1 gene therapy attenuates atherosclerosis and stabilizes plaques in apolipoprotein E-deficient mice. Hum. Gene Ther. 19, 287-299.

131. Tabas, I. (2010) Macrophage death and defective inflammation resolution in atherosclerosis. Nat. Rev. Immunol. 10, 36-46.

132. Weber, C., Zernecke, A., and Libby, P. (2008) The multifaceted contributions of leukocyte subsets to atherosclerosis: lessons from mouse models. Nat. Rev. Immunol. 8, 802-815.

133. Natarajan, C., Muthian, G., Barak, Y., Evans, R.M., and Bright, J.J. (2003) Peroxisome proliferator-activated receptor-gamma-deficient heterozygous mice develop an exacerbated neural antigen-induced Th1 response and experimental allergic encephalomyelitis. J. Immunol. 171, 5743-5750.

134. Feinstein, D.L., Galea, E., Gavrilyuk, V., Brosnan, C.F., Whitacre, C.C., Dumitrescu-Ozimek, L., Landreth, G.E., Pershadsingh, H.A., Weinberg, G., and Heneka, M.T. (2002) Peroxisome proliferator-activated receptor-gamma agonists prevent experimental autoimmune encephalomyelitis. Ann. Neurol. 51, 694-702.

135. Kielian, T. and Drew, P.D. (2003) Effects of peroxisome proliferator-activated receptor-gamma agonists on central nervous system inflammation. J. Neurosci. Res. 71, 315-325.

136. Niino, M., Iwabuchi, K., Kikuchi, S., Ato, M., Morohashi, T., Ogata, A., Tashiro, K., and Onoe, K. (2001) Amelioration of experimental autoimmune encephalomyelitis in C57BL/6 mice by an agonist of peroxisome proliferator-activated receptor-gamma. J. Neuroimmunol. 116, 40-48.

137. Su, C.G., Wen, X., Bailey, S.T., Jiang, W., Rangwala, S.M., Keilbaugh, S.A., Flanigan, A., Murthy, S., Lazar, M.A., and Wu, G.D. (1999) A novel therapy for colitis utilizing PPAR-gamma ligands to inhibit the epithelial inflammatory response. J. Clin. Invest. 104, 383-389. 
138. Sanchez-Hidalgo, M., Martin, A.R., Villegas, I., and de la Lastra, C.A. (2007) Rosiglitazone, a PPARgamma ligand, modulates signal transduction pathways during the development of acute TNBS-induced colitis in rats. Eur. J. Pharmacol. 562, 247-258.

139. Tanaka, T., Kohno, H., Yoshitani, S., Takashima, S., Okumura, A., Murakami, A., and Hosokawa, M. (2001) Ligands for peroxisome proliferator-activated receptors alpha and gamma inhibit chemically induced colitis and formation of aberrant crypt foci in rats. Cancer Res. 61, 2424-2428.

140. Saubermann, L.J., Nakajima, A., Wada, K., Zhao, S., Terauchi, Y., Kadowaki, T., Aburatani, H., Matsuhashi, N., Nagai, R., and Blumberg, R.S. (2002) Peroxisome proliferator-activated receptor gamma agonist ligands stimulate a Th2 cytokine response and prevent acute colitis. Inflamm. Bowel Dis. 8, 330-339.

141. Cuzzocrea, S., Mazzon, E., Dugo, L., Patel, N.S., Serraino, I., Di Paola, R., Genovese, T., Britti, D., De Maio, M., Caputi, A.P., and Thiemermann, C. (2003) Reduction in the evolution of murine type II collagen-induced arthritis by treatment with rosiglitazone, a ligand of the peroxisome proliferator-activated receptor gamma. Arthritis Rheum. 48, 3544-3556.

142. Setoguchi, K., Misaki, Y., Terauchi, Y., Yamauchi, T., Kawahata, K., Kadowaki, T., and Yamamoto, K. (2001) Peroxisome proliferator-activated receptor-gamma haploinsufficiency enhances B cell proliferative responses and exacerbates experimentally induced arthritis. J. Clin. Invest. 108, 1667-1675.

143. Shiojiri, T., Wada, K., Nakajima, A., Katayama, K., Shibuya, A., Kudo, C., Kadowaki, T., Mayumi, T., Yura, Y., and Kamisaki, Y. (2002) PPAR gamma ligands inhibit nitrotyrosine formation and inflammatory mediator expressions in adjuvant-induced rheumatoid arthritis mice. Eur. J. Pharmacol. 448, 231-238.

144. Xu, H., Barnes, G.T., Yang, Q., Tan, G., Yang, D., Chou, C.J., Sole, J., Nichols, A., Ross, J.S., Tartaglia, L.A., and Chen, H. (2003) Chronic inflammation in fat plays a crucial role in the development of obesity-related insulin resistance. J. Clin. Invest. 112, 1821-1830.

145. Lee, K.S., Park, S.J., Kim, S.R., Min, K.H., Jin, S.M., Lee, H.K., and Lee, Y.C. (2006) Modulation of airway remodeling and airway inflammation by peroxisome proliferator-activated receptor gamma in a murine model of toluene diisocyanate-induced asthma. J. Immunol. 177, 5248-5257.

146. Belvisi, M.G., Hele, D.J., and Birrell, M.A. (2006) Peroxisome proliferator-activated receptor gamma agonists as therapy for chronic airway inflammation. Eur. J. Pharmacol. 533, 101-109.

147. Ivashchenko, C.Y., Duan, S.Z., Usher, M.G., and Mortensen, R.M. (2007) PPAR-gamma knockout in pancreatic epithelial cells abolishes the inhibitory effect of rosiglitazone on caerulein-induced acute pancreatitis. Am. J. Physiol. Gastrointest. Liver Physiol. 293, G319-326.

148. Demerjian, M., Man, M.Q., Choi, E.H., Brown, B.E., Crumrine, D., Chang, S., Mauro, T., Elias, P.M., and Feingold, K.R. (2006) Topical treatment with thiazolidinediones, activators of peroxisome proliferator-activated receptorgamma, normalizes epidermal homeostasis in a murine hyperproliferative disease model. Exp. Dermatol. 15, 154160.

149. Cuzzocrea, S., Pisano, B., Dugo, L., Ianaro, A., Maffia, P., Patel, N.S., Di Paola, R., Ialenti, A., Genovese, T., Chatterjee, P.K., Di Rosa, M., Caputi, A.P., and Thiemermann, C. (2004) Rosiglitazone, a ligand of the peroxisome proliferator-activated receptor-gamma, reduces acute inflammation. Eur. J. Pharmacol. 483, 79-93.

150. Hall, J.M. and McDonnell, D.P. (2007) The molecular mechanisms underlying the proinflammatory actions of thiazolidinediones in human macrophages. Mol. Endocrinol. 21, 1756-1768.

\section{This article should be cited as follows:}

Schmidt M.V., Brüne, B., and von Knethen, A. (2010) The nuclear hormone receptor PPAR $\gamma$ as a therapeutic target in major diseases. TheScientificWorldJOURNAL 10, 2181-2197. DOI 10.1100/tsw.2010.213. 

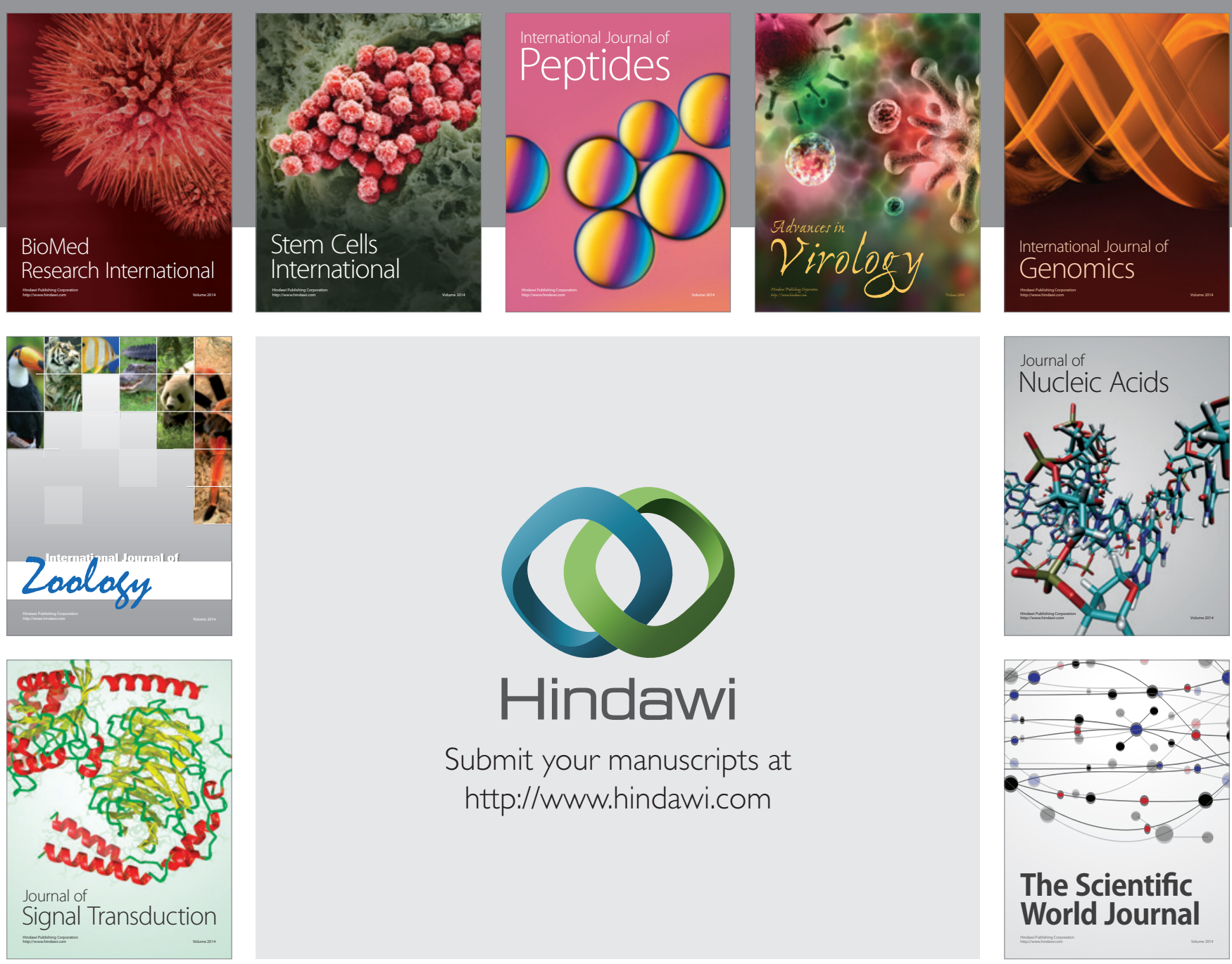

Submit your manuscripts at

http://www.hindawi.com
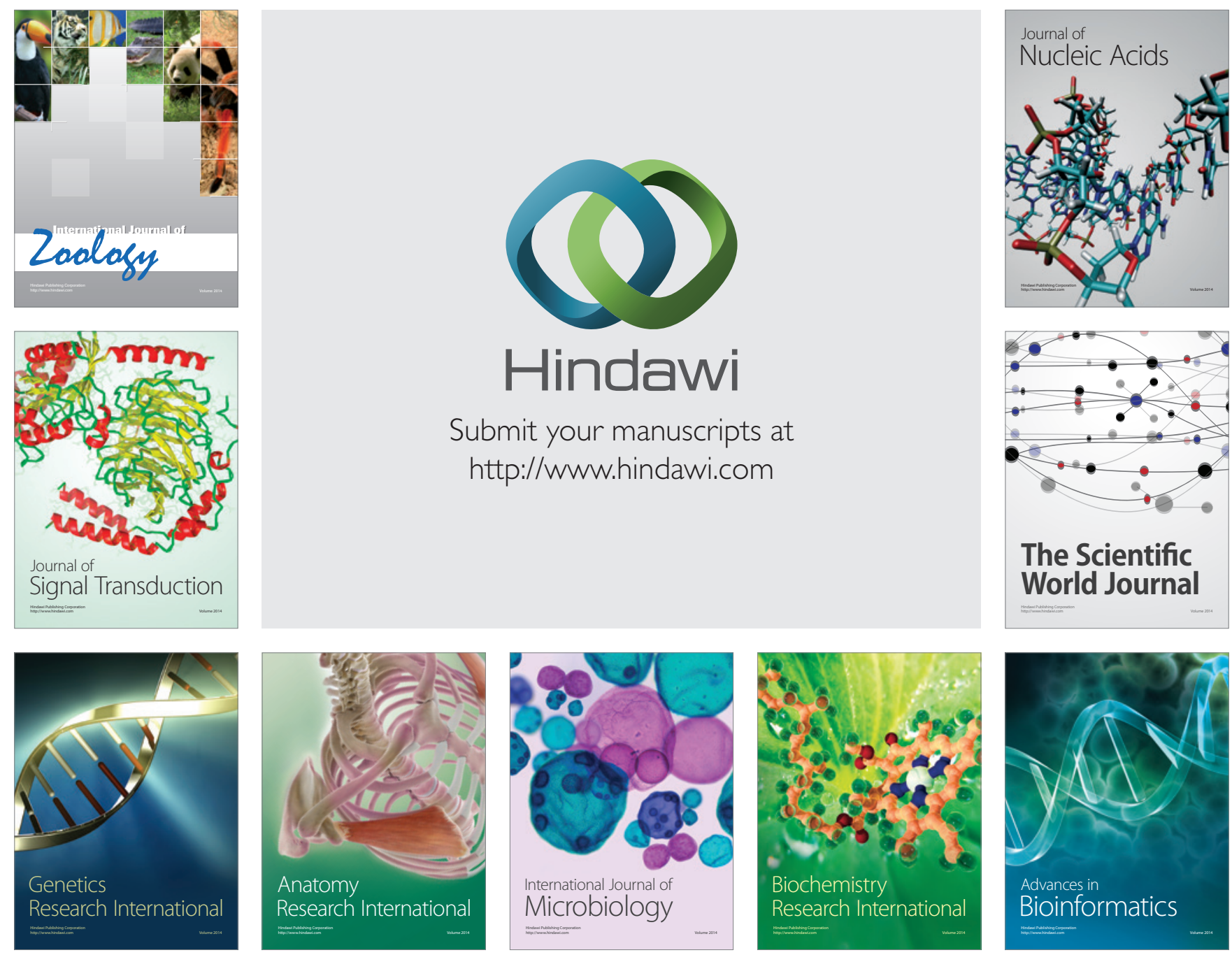

The Scientific World Journal
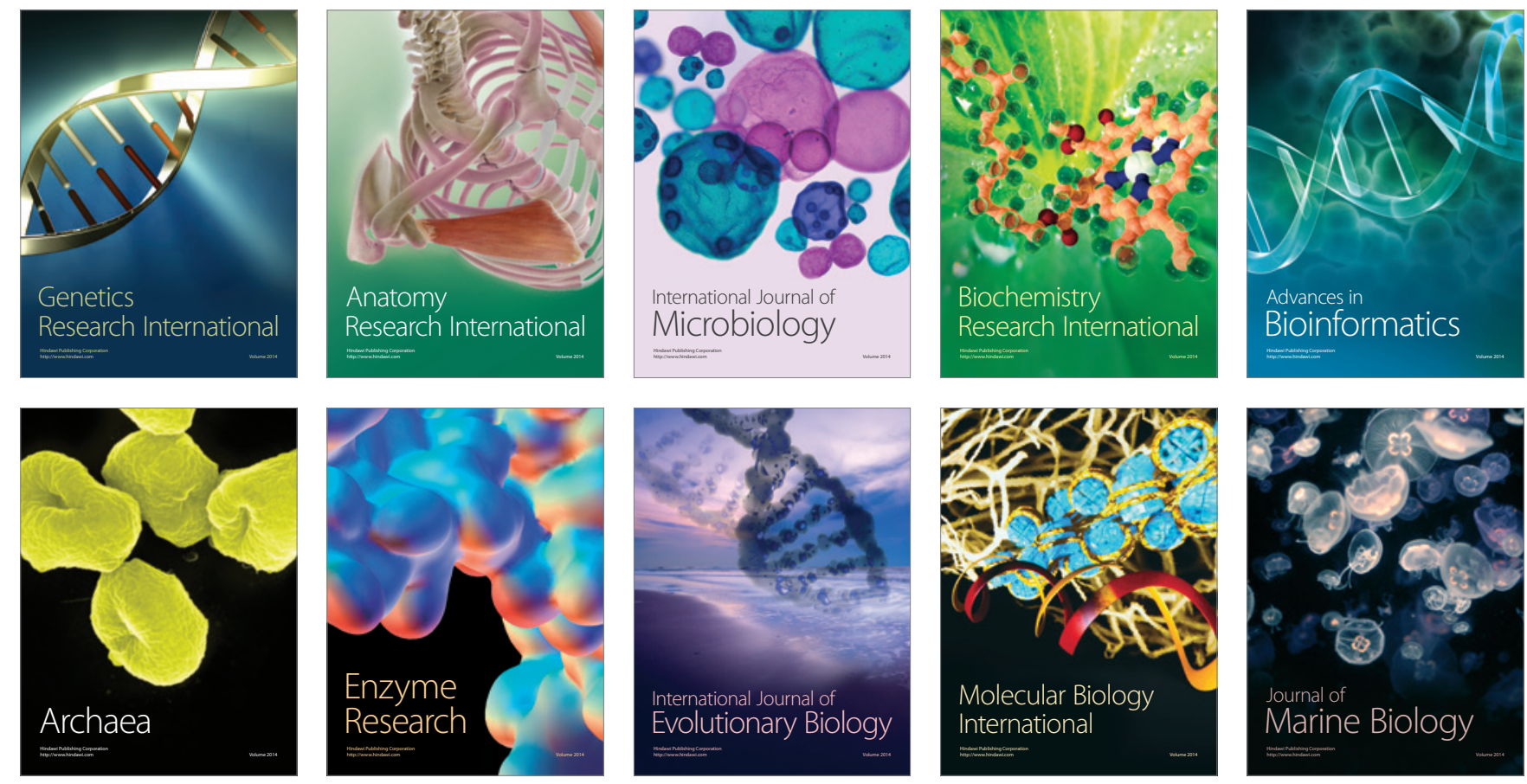